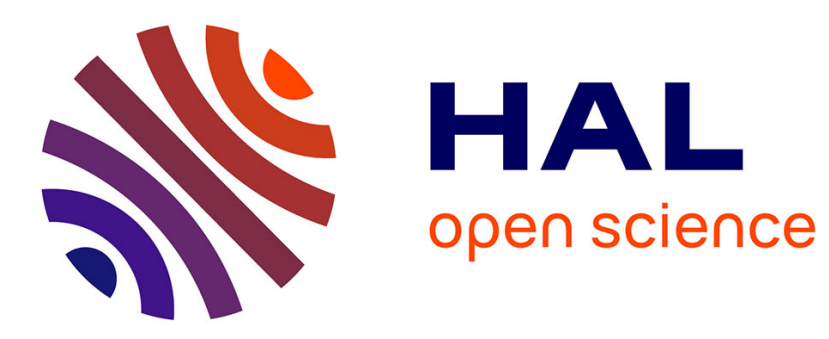

\title{
Rare earth elements dynamics along pedogenesis in a chronosequence of podzolic soils
}

Marie Vermeire, Sophie Cornu, Zuzana Fekiacova, Marie Detienne, Bruno Delvaux, Jean-Thomas Cornélis

\section{- To cite this version:}

Marie Vermeire, Sophie Cornu, Zuzana Fekiacova, Marie Detienne, Bruno Delvaux, et al.. Rare earth elements dynamics along pedogenesis in a chronosequence of podzolic soils. Chemical Geology, 2016, 446, pp.163 - 174. 10.1016/j.chemgeo.2016.06.008 . hal-01466196

\section{HAL Id: hal-01466196 \\ https://hal.science/hal-01466196}

Submitted on 13 Feb 2017

HAL is a multi-disciplinary open access archive for the deposit and dissemination of scientific research documents, whether they are published or not. The documents may come from teaching and research institutions in France or abroad, or from public or private research centers.
L'archive ouverte pluridisciplinaire HAL, est destinée au dépôt et à la diffusion de documents scientifiques de niveau recherche, publiés ou non, émanant des établissements d'enseignement et de recherche français ou étrangers, des laboratoires publics ou privés. 


\title{
Rare earth elements dynamics along pedogenesis in a chronosequence of podzolic soils
}

\author{
Marie-Liesse Vermeire ${ }^{\mathrm{a}, *}$, Sophie Cornu ${ }^{\mathrm{b}}$, Zuzana Fekiacova ${ }^{\mathrm{b}}$, Marie Detienne ${ }^{\mathrm{a}}$, \\ Bruno Delvaux ${ }^{a}$, Jean-Thomas Cornélis ${ }^{c}$ \\ a Université catholique de Louvain, Earth and Life Institute, ELIe, Croix du Sud 2 bte L7.05.10, 1348, Louvain-la-Neuve, Belgium \\ b Aix-Marseille Université, CNRS, IRD, CEREGE UM34 et USC INRA, 13545, Aix en Provence, France \\ c Soil-Water-Plant Exchanges, Gembloux Agro-Bio Tech, University of Liège, Avenue Maréchal Juin 27, 5030 Gembloux, Belgium
}

\section{A R T I C L E I N F O}

\section{Article history:}

Received 30 September 2015

Received in revised form 8 June 2016

Accepted 9 June 2016

Available online 11 June 2016

\section{Keywords:}

Lanthanides

Soil evolution rate

Podzolization

Weathering

Secondary phases

\begin{abstract}
A B S T R A C T
Rare earth elements (REE) total concentration and signature in soils are known to be impacted by successive soilforming processes. So it can be used as probe of soil processes. However, few studies focus on their behavior in Podzols. Podzols result from the combination of two main pedogenic processes: (1) the strong weathering in the surface eluvial horizon; (2) the downward transfer of dissolved organic matter (OM) and mobile $\mathrm{Al}$ and $\mathrm{Fe}$, and their accumulation in the illuvial horizon beneath. Iron oxides and OM are known to have strong affinities with REE, and to play an important role in transfer and immobilization of REE. In order to decipher the relative importance of Fe oxide and OM in REE fate during podzolization, and to investigate whether REE can trace Podzol formation, we study here the evolution of REE signatures along five pedons, aged from 120 to 530 years, in a Cambisol-Podzol chronosequence located in the Cox Bay of Vancouver Island. Our results show that the REE content is strongly correlated to the general loss of elements and mineral weathering. Furthermore, the accumulation of secondary OM, Al and Fe-bearing phases does not impact the REE signature of the bulk soil. Both our results and the ones available in the literature indicate that the release of REE induced by weathering and subsequent leaching in percolating water are the main pathways determining the REE fate in Podzols. Furthermore, we show that REE can be released and mobilized in very short periods of time during podzolization (330 years).
\end{abstract}

(c) 2016 Elsevier B.V. All rights reserved.

\section{Introduction}

The group of rare earth elements (REE) consists of 17 elements; the lanthanides and lanthanum (La) together with scandium (Sc) and yttrium (Y) (Saatz et al., 2015). They form a series that behaves geochemically coherently owing to the small but steady decrease in ionic radius with increase in atomic number (Henderson, 1984; Panahi et al., 2000; Yusoff et al., 2013). They are considered as promising tracers in pedogenesis (Taunton et al., 2000; Aubert et al., 2001; Aide and Smith-Aide, 2003; Chabaux et al., 2003; Compton et al., 2003; Ndjigui et al., 2008; Laveuf and Cornu, 2009; Harlavan et al., 2009; Ma et al., 2011; Gong et al., 2011; Yusoff et al., 2013). The origin of REE in soils lies in the parent material (PM), since anthropogenic sources are restricted (Hu et al., 2006). During pedogenesis, REE signature is affected by a variety of processes (dissolution, oxydo-reduction, precipitation

\footnotetext{
* Corresponding author.

E-mail addresses: Marie-liesse.vermeire@uclouvain.be (M.-L. Vermeire) Sophie.cornu@aix.inra.fr (S.Cornu),Zuzana.Fekiacova@aix.inra.fr (Z. Fekiacova), Marie.detienne@uclouvain.be (M. Detienne),Bruno.delvaux@uclouvain.be (B. Delvaux), jtcornelis@ulg.ac.be (J.-T. Cornélis).
}

and complexation). These processes induce internal fractionations and/or anomalies related to REE mass or different oxidation states for $\mathrm{Ce}$ and Eu. Consequently, REE concentrations normalized to a reference PM and fractionation pattern observed in a soil profile provide a useful tool for elucidating soil-forming processes leading to the formation of a specific soil horizon (Yusoff et al., 2013).

Iron- and Mn-oxides are known to scavenge REE (Rankin and Childs, 1976; Palumbo et al., 2001) through one or a combination of the following mechanisms: coprecipitation, adsorption, surface complex formation, ion exchange and penetration of the lattice (Chao, 1976; Cao et al., 2001), in amounts varying with soil type (Li et al., 2006; Wang et al., 2001; Zhang and Shan, 2001) and depth (Land et al., 1999; Yan et al., 1999). Soil organic matter (SOM) is more efficient than Fe oxides in concentrating REE, given the strong complexing ability of organic molecules (Davranche et al., 2011). Therefore, SOM plays an important role in the transfer and immobilization of REE, controlling inter-horizon REE distribution (Koeppenkastrop and De Carlo, 1992; Tang and Johannesson, 2003; Pourret et al., 2007a; Goyne et al., 2010; Davranche et al., 2011; Aide and Aide, 2012). The differential binding affinity of the REE for SOM across the REE series is still poorly understood. Two general tendencies can be observed in natural waters (Tang and 
Johannesson, 2010): trend $\mathbf{M}$ and trend $\mathrm{H}$. The trend $\mathbf{M}$ is observed in the liquid phase if the stability constants of REE-Humic substances complexes are greatest for the middle REE (MREE), followed by the heavy REE (HREE), and light REE (LREE). The M trend gives a MREE enrichment signature in the liquid phase (Johannesson et al., 2004; Yamamoto et al., 2005; Pourret et al., 2007b; Pedrot et al., 2008; Tang and Johannesson, 2010; Davranche et al., 2011; Cidu et al., 2013). The trend $\mathbf{H}$ is observed if the stability constants of REE-Humic substances increase with increasing atomic number across the REE series. They are thus largest for the HREE; this is called "lanthanide contraction effect" (Sonke and Salters, 2006; Sonke, 2006; Stern et al., 2007; Laveuf and Cornu, 2009; Gangloff et al., 2014; Vázquez-Ortega et al., 2015).

Podzolization combines two main processes: (1) strong mineral weathering in the eluvial surface E horizon, eventually depleted in elements and enriched in resistant minerals as quartz and resistant accessory minerals, and characterized by a light-grey color; (2) eluviation with percolating water of dissolved organic matter (DOM) complexed with $\mathrm{Al}$ and Fe which will precipitate and accumulate in soil horizons beneath to form dark reddish/brownish colored illuvial horizons (Bh, Bhs or Bs) (Lundström et al., 2000). Among the mechanisms that have been proposed to explain mobilization and translocation phenomenon involved in podzolization, the formation and downward transport of unsaturated complexes of organic acids with $\mathrm{Al}$ and $\mathrm{Fe}$ (the fulvate theory, McKeague et al. (1978)) has been generally accepted as the dominant mechanism of eluviation (Lundström et al., 2000). Dissolved organic acids are crucial components in Podzol development, both because they demonstrate a large ability to promote dissolution of minerals, and they form complexes with $\mathrm{Al}$ and $\mathrm{Fe}$, that will transport those elements deeper in the soil profile (van Hees et al., 2000; Lundström et al., 2000; Kaiser and Kalbitz, 2012; Gangloff et al., 2014). These reactions can be fast ( 100 years) depending on environmental conditions (Sauer et al., 2008; Cornu et al., 2008). As metal cations and DOM play a key role in podzolization process, it is reasonable to hypothesize that the REE signature of the soil will be impacted by a podzolic development.

In order to understand the REE's temporal dynamics along with Fe and OM fate in Podzol, and to assess the ability of REE to trace this pedogenic processes, we study the REE distribution in a podzolic soil chronosequence. The soil members of the chronosequence were already characterized. Besides, they exhibit successive processes in terms of dissolution, synthesis and transfer of clay minerals (Cornelis et al., 2014) as well as a strong redistribution in Fe and OM. A chronosequence involves a sequence of soils developed in the same conditions of soil forming factors except time (Huggett, 1998; Walker et al., 2010). They are valuable tools for investigating temporal dynamics of pedogenic processes.

\section{Material and methods}

\subsection{Study area}

The study site is a chronosequence under Sitka spruce (Picea sitchensis) forest, located near Cox Bay, on the west coast of Vancouver Island, British Columbia (latitude $49^{\circ} 6^{\prime} \mathrm{N}$, longitude $125^{\circ} 52^{\prime} \mathrm{W}$ ). Climate is characterized by a lack of temperature extremes and abundant precipitation (annual precipitation $3200 \mathrm{~mm}$ and average temperature $8.9^{\circ} \mathrm{C}$ ) (Singleton and Lavkulich, 1987; Lundström et al., 2000). Due to rainfall, moderate temperature and close proximity to the ocean, the humidity remains high throughout the year (between 75 and 95\%) (Cordes, 1972). The incoming ocean spray brings significant amount of $\mathrm{Na}, \mathrm{Mg}$, Ca and $\mathrm{K}$ to soils. Such an input improves the soil nutrient status, without inducing nutrient accumulation, because of rainfall at the site (Cordes, 1972). The soils have developed on Cox Bay beach sand deposits, which are advancing towards the ocean in a configuration parallel to the existing shoreline at a rate of $0.26 \mathrm{~m}$ per year (Singleton and Lavkulich, 1987). Only slight variations in parent materials suggest a uniform depositional sequence in the study area (Singleton and
Lavkulich, 1987). The source of the beach sand parent material is the Tofino Area Greywacke Unit (Muller and Carson, 1969; Singleton and Lavkulich, 1987).

\subsection{Soil chronosequence}

Five pedons (P) (P1-120 years, P2-175 years, P3-270 years, P4330 years and $\mathrm{P} 5-530$ years) were selected along a transect ( 0 $147 \mathrm{~m}$ ) perpendicular to the present shoreline (Singleton and Lavkulich, 1987; Cornelis et al., 2014). One representative sample was taken per horizon, as described in Table 1 . The respective ages of the profiles were determined by dendrochronology (tree-rings dating). As a strip of sand of approximately $13 \mathrm{~m}$ wide lies between the active beach and the sand deposits containing tree seedlings, 50 years (time needed for this strip to accumulate) were added to the tree age estimated for each site to determine the site ages (Singleton and Lavkulich, 1987). Increasing soil development, and consequently progressive deepening and differentiation of genetic horizons during podzolization, is observed in the transect with increasing distance from the active beach (Cornelis et al., 2014). According to the IUSS Working Group WRB system (World Reference Base for Soil Resources, 2014) the soils are classified as Dystric Cambisol at the youngest sites (P1-120 and P2-175), Albic Podzol at the intermediate site (P3-270), and Placic Podzol at the oldest sites (P4-335 and P5-530). The Placic Podzols are characterized by the following sequence of soil horizons from surface to depth (Cornelis et al., 2014): an eluvial albic E horizon, strongly weathered; an illuvial spodic Bh horizon (enriched in OM); a Bhs horizon, enriched in Fe oxyhydroxides and OM; a Bs horizon, enriched in poorly crystalline aluminosilicates and Fe oxyhydroxides; a Bw horizon characterized by its color and structure but exhibiting no illuvial accumulation; and a poorly structured BC horizon (Fig. 1, Table 1).

Sitka spruce ( $P$. sitchensis) alone is the forest cover at the youngest site (P1-120). It is associated with (1) salal (Gaultheria shallon) at P2175 and P3-270 sites, and with (2) salal (G. shallon), western red cedar (Thuja plicata), western hemlock (Tsuga heterophylla), douglas fir (Pseudotsuga menziesii) and western sword fern (Polystichum munitum) at the oldest sites (P4-335 and P5-530) (Cornelis et al., 2014).

\subsection{Analytical methods}

The soil samples were air-dried and sieved at $2 \mathrm{~mm}$ according to NF ISO 11464. Classical soil characterizations were performed (Tables 1 and 2). Soil pH was measured in $5 \mathrm{~g}: 25 \mathrm{ml}$ soil:water suspension (Page et al., 1982). Cation exchange capacity (CEC) and the content of exchangeable cations were determined, according to Page et al. (1982), in ammonium acetate $1 \mathrm{M}$ at $\mathrm{pH} 7$ and measured by ICP-AES. Soil particle-size analysis was achieved by quantitative recovery of clay $(<2 \mu \mathrm{m})$, silt $(2-50 \mu \mathrm{m})$ and sand $(>50 \mu \mathrm{m})$ fractions after sonication and dispersion with $\mathrm{Na}^{+}$-saturated resins without any previous $\mathrm{H}_{2} \mathrm{O}_{2}$ oxidation of OM, as described in Henriet et al. (2008). Total major elemental contents were measured by inductively coupled plasma/atomic emission spectrometry (ICP-AES) after fusion in Li-metaborate + Li-tetraborate at $1000{ }^{\circ} \mathrm{C}$ (Chao and Sanzolone, 1992). This was performed on samples prepared according to NF ISO 11464 and crushed to $<250 \mu \mathrm{m}$ as recommended by $\mathrm{NF} \times 31147$. The total reserve in bases (TRB) is the sum of the total contents of alkaline and alkaline-earth cations $\left(\mathrm{Na}^{+}, \mathrm{K}^{+}\right.$, $\mathrm{Ca}^{2+}, \mathrm{Mg}^{2+}$; in cmolc $\left.\cdot \mathrm{kg}^{-1}\right)$. TRB directly measures the weathering stage of soil because it estimates the content of weatherable minerals (Herbillon, 1986). Total organic carbon concentration was determined by dry combustion (Flash EA 1112 series elemental analyzer, combustion temperature $>960^{\circ} \mathrm{C}$ ).

$\mathrm{Si}$, Fe and Al linked to different soil components were selectively extracted from the fine earth soil fractions ( $<2 \mathrm{~mm}$ fraction, uncrushed) using sodium pyrophosphate, dark oxalate and dithionite-citrate-bicarbonate (DCB) following the methods of Bascomb (1968); Blakemore et al. (1987), and Mehra and Jackson (1960), respectively. The fractions 
Table 1

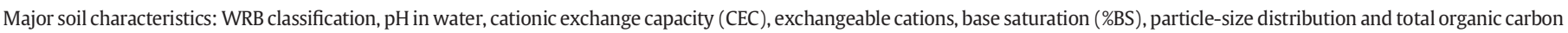
(TOC) content.

\begin{tabular}{|c|c|c|c|c|c|c|c|c|c|c|c|c|c|c|c|}
\hline \multirow[t]{2}{*}{ Profile } & \multirow[t]{2}{*}{ Age } & \multirow[t]{2}{*}{ Horizon } & \multirow{2}{*}{$\begin{array}{l}\text { Depth } \\
\mathrm{cm}\end{array}$} & \multirow[t]{2}{*}{$\mathrm{WRB}^{\mathrm{a}}$} & \multirow{2}{*}{$\frac{\mathrm{pH}}{\text { (Water) }}$} & \multirow{2}{*}{$\begin{array}{l}\text { CEC } \\
\mathrm{cmolc} / \mathrm{kg}\end{array}$} & \multicolumn{4}{|c|}{ Exchangeable cations ( $\mathrm{cmolc} \mathrm{kg}^{-1}$ ) } & \multirow[t]{2}{*}{$\% \mathrm{BS}$} & \multicolumn{3}{|c|}{$\begin{array}{l}\text { Particle size } \\
\text { distribution (\%) }\end{array}$} & \multirow{2}{*}{$\begin{array}{l}\text { TOC } \\
\overline{\mathrm{g} \mathrm{kg}^{-1}}\end{array}$} \\
\hline & & & & & & & $\mathrm{Ca}^{2+}$ & $\mathrm{K}^{+}$ & $\mathrm{Mg}^{2+}$ & $\mathrm{Na}^{+}$ & & Sand & Silt & Clay & \\
\hline P.M. $^{\text {b }}$ & 0 & $\mathrm{C}$ & & & 7.7 & 1.55 & 0.19 & 0.23 & 0.33 & 0.73 & 95.57 & 99.9 & 0.1 & 0.0 & 0.32 \\
\hline P1 & 120 & BC1 & $0-35$ & DC & 5.9 & 3.72 & 0.25 & 0.10 & 0.35 & 0.18 & 23.76 & 99.2 & 0.6 & 0.3 & 9.12 \\
\hline P1 & 120 & $\mathrm{BC} 2$ & $35-60$ & DC & 5.9 & 3.32 & 0.23 & 0.06 & 0.33 & 0.18 & 24.21 & & & & 7.79 \\
\hline P2 & 175 & BW & $3-44$ & DC & 5.8 & 4.34 & 0.23 & 0.07 & 0.35 & 0.25 & 20.66 & 99.0 & 0.6 & 0.4 & 3.33 \\
\hline P2 & 175 & $\mathrm{BC}$ & $44-75$ & DC & 5.9 & 2.38 & 0.12 & 0.08 & 0.18 & 0.22 & 25.30 & 99.6 & 0.2 & 0.1 & 2.55 \\
\hline P3 & 270 & $\mathrm{E}$ & $0-7$ & $\mathrm{AP}$ & 4.6 & 6.04 & 0.48 & 0.05 & 0.56 & 0.11 & 19.94 & 90.8 & 6.1 & 3.1 & 12.63 \\
\hline P3 & 270 & $\mathrm{Bh}$ & $7-23$ & $\mathrm{AP}$ & 5.1 & 5.94 & 0.59 & 0.04 & 0.41 & 0.13 & 19.76 & 97.2 & 1.7 & 1.1 & 16.17 \\
\hline P3 & 270 & BW & $23-57$ & $\mathrm{AP}$ & 5.3 & 5.57 & 0.52 & 0.04 & 0.40 & 0.11 & 19.14 & 97.4 & 1.8 & 0.9 & 8.18 \\
\hline P3 & 270 & $\mathrm{BC}$ & $>57$ & AP & 5.4 & 5.71 & 0.39 & 0.10 & 0.22 & 0.11 & 14.53 & 98.2 & 1.1 & 0.7 & 6.87 \\
\hline P4 & 330 & $\mathrm{E}$ & $0-10$ & $\mathrm{PP}$ & 4.9 & 5.66 & 0.07 & 0.02 & 0.05 & 0.04 & 3.22 & 82.3 & 14.4 & 3.3 & 8.48 \\
\hline P4 & 330 & $\mathrm{Bh}$ & $10-17$ & $\mathrm{PP}$ & 5.5 & 15.72 & 0.22 & 0.04 & 0.10 & 0.06 & 2.67 & 88.0 & 8.7 & 3.2 & 16.18 \\
\hline P4 & 330 & Bhs & $17-17.5$ & PP & & 15.18 & 0.13 & 0.04 & 0.07 & 0.06 & 1.96 & 90.0 & 6.8 & 3.2 & 22.99 \\
\hline P4 & 330 & Bs & $17.5-23$ & PP & 5.3 & 5.88 & 0.04 & 0.03 & 0.01 & 0.03 & 1.80 & 94.9 & 4.2 & 0.9 & 4.53 \\
\hline P4 & 330 & Bw & $23-63$ & $\mathrm{PP}$ & 5.4 & 4.31 & 0.03 & 0.03 & 0.01 & 0.04 & 2.58 & 96.1 & 2.4 & 1.5 & 2.67 \\
\hline P4 & 330 & $\mathrm{BC} 1$ & $63-113$ & $\mathrm{PP}$ & 5.3 & 3.15 & 0.02 & 0.06 & 0.00 & 0.02 & 3.21 & & & & 1.26 \\
\hline P4 & 330 & $\mathrm{BC} 2$ & 113-193 & PP & 5.3 & 2.72 & 0.02 & 0.01 & 0.00 & 0.02 & 2.33 & & & & 1.48 \\
\hline P4 & 330 & $\mathrm{BC} 3$ & $>193$ & PP & 5.2 & 2.71 & 0.02 & 0.04 & 0.00 & 0.02 & 3.14 & 98.2 & 1.8 & 0.0 & 1.03 \\
\hline P5 & 530 & $\mathrm{E}$ & $0-8$ & PP & 4.5 & 5.31 & 0.22 & 0.04 & 0.15 & 0.06 & 8.63 & & & & 31.90 \\
\hline P5 & 530 & $\mathrm{Bh}$ & $8-9.5$ & PP & 4.5 & 15.32 & 0.33 & 0.03 & 0.16 & 0.06 & 3.78 & & & & 31.18 \\
\hline P5 & 530 & Bhs & $9.5-10$ & $\mathrm{PP}$ & 4.5 & 23.35 & 0.24 & 0.08 & 0.13 & 0.07 & 2.23 & & & & 40.48 \\
\hline P5 & 530 & Bs & $10-15$ & PP & 4.8 & 9.85 & 0.04 & 0.04 & 0.03 & 0.04 & 1.60 & & & & 11.60 \\
\hline P5 & 530 & Bw & $15-40$ & $\mathrm{PP}$ & 5.0 & 3.53 & 0.02 & 0.01 & 0.00 & 0.03 & 2.02 & & & & 1.17 \\
\hline P5 & 530 & $\mathrm{BC}$ & $40-60$ & PP & 5.1 & 2.45 & 0.03 & 0.02 & 0.00 & 0.01 & 2.56 & & & & 0.64 \\
\hline
\end{tabular}

a WRB classification: DC stands for Dystric Cambisol, AP for Albic Podzol and PP for Placic Podzol.

b PM: parental material.

obtained with pyrophosphate $\left(\mathrm{Al}_{\mathrm{p}}, \mathrm{Fe}_{\mathrm{p}}\right)$ indicate principally $\mathrm{Al}$ and $\mathrm{Fe}$ present in organo-metallic complexes. The fraction obtained with oxalate $\left(\mathrm{Al}_{\mathrm{o}}, \mathrm{Fe}_{\mathrm{o}}, \mathrm{Si}_{\mathrm{o}}\right)$ comprises principally i) $\mathrm{Al}$ and $\mathrm{Fe}$ in organic complexes, ii) Al and Fe in non-crystalline (hydr)oxides, iii) $\mathrm{Al}$ and $\mathrm{Si}$ in poorly crystalline aluminosilicates. The fractions obtained with sodium dithionite/citrate $\left(\mathrm{Al}_{\mathrm{d}}, \mathrm{Fe}_{\mathrm{d}}\right)$ comprise i) $\mathrm{Al}$ and $\mathrm{Fe}$ in organic
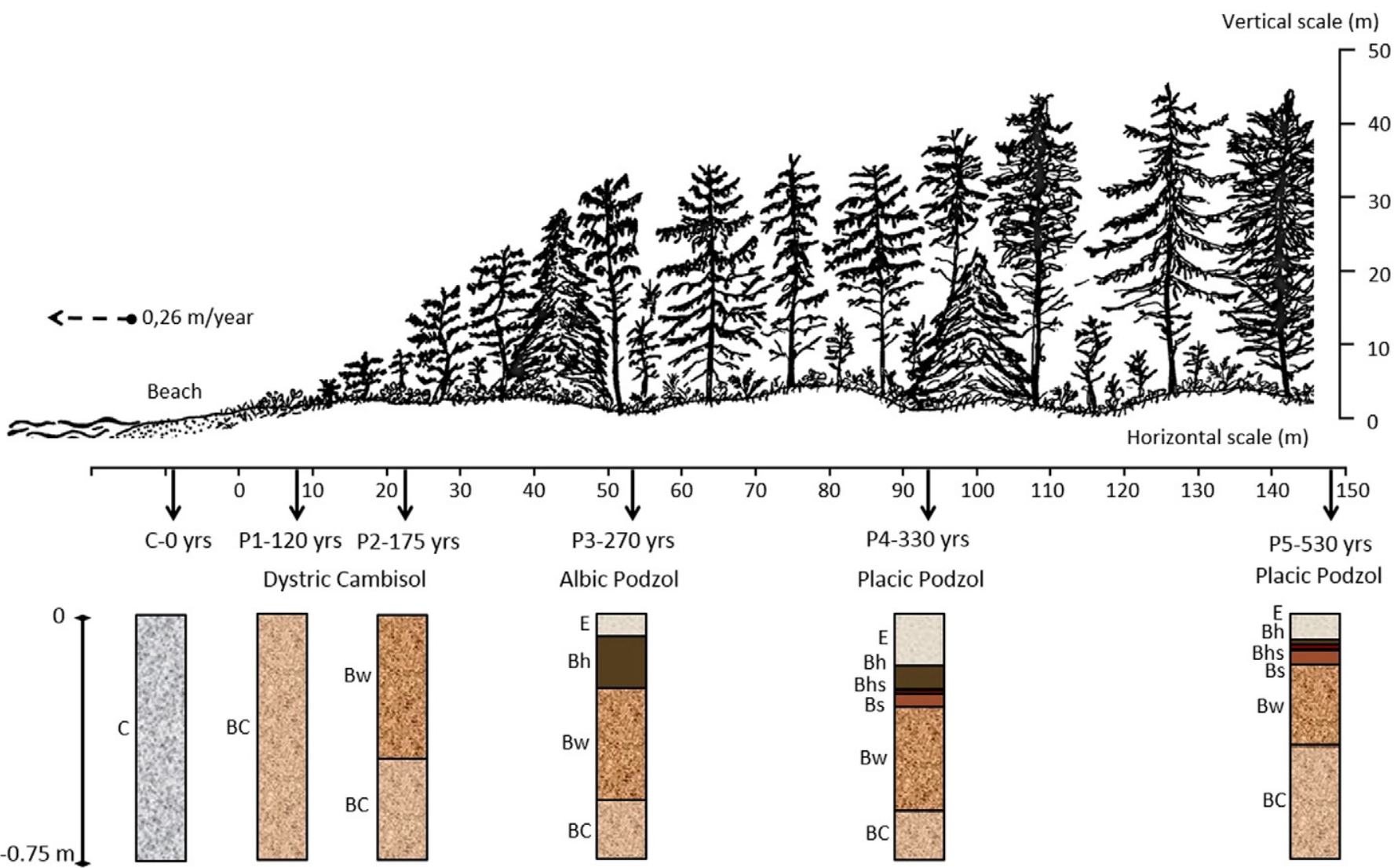

$-0.75 \mathrm{~m}$

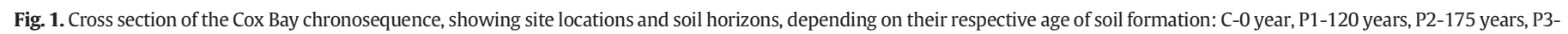
270 years, P4-330 years and P5-530 years (modified from Cornelis et al., 2014). 
Table 2

Total elemental contents of the bulk soil, total reserve in bases (TRB) and proportion of 'free iron' as measured by the ratio between $\mathrm{DCB}$-extractable iron and total iron ( $\mathrm{Fe} \mathrm{e}_{\mathrm{d}} / \mathrm{Fe}_{\mathrm{t}}$ ).

\begin{tabular}{|c|c|c|c|c|c|c|c|c|c|c|c|c|c|c|c|c|c|}
\hline \multirow[t]{2}{*}{ Profile } & \multirow[t]{2}{*}{ Horizon } & \multirow{2}{*}{$\frac{\text { Depth }}{\mathrm{cm}}$} & \multicolumn{13}{|c|}{ Total elemental content $\left(\mathrm{g} \mathrm{kg}^{-1}\right)$} & \multirow{2}{*}{$\frac{\text { TRB }}{\mathrm{cmolc} / \mathrm{kg}}$} & \multirow[t]{2}{*}{$\mathrm{Fe}_{\mathrm{d}} / \mathrm{Fe}_{\mathrm{t}}$} \\
\hline & & & $\mathrm{Si}$ & Al & $\mathrm{Fe}$ & $\mathrm{Ca}$ & $\mathrm{K}$ & $\mathrm{Mg}$ & $\mathrm{Na}$ & $\mathrm{Ba}$ & $\mathrm{Mn}$ & $\mathrm{P}$ & $\mathrm{Sr}$ & $\mathrm{Zr}$ & $\mathrm{Ti}$ & & \\
\hline P.M. & C & & 285.27 & 75.87 & 48.92 & 55.63 & 5.93 & 18.03 & 21.50 & 0.29 & 1.18 & 0.67 & 0.44 & 0.23 & 7.14 & 534.67 & 0.03 \\
\hline P1-120 & BC1 & $0-35$ & 302.71 & 70.95 & 34.47 & 42.72 & 6.57 & 13.31 & 22.94 & 0.31 & 0.74 & 0.55 & 0.38 & 0.10 & 4.37 & 439.32 & 0.05 \\
\hline P1-120 & $\mathrm{BC} 2$ & $35-60$ & 293.11 & 73.67 & 41.94 & 49.93 & 6.23 & 16.01 & 21.58 & 0.30 & 0.96 & 0.57 & 0.42 & 0.13 & 5.89 & 490.74 & 0.05 \\
\hline P2-175 & Bw & $3-44$ & 309.65 & 70.01 & 33.62 & 39.85 & 6.89 & 13.20 & 24.23 & 0.32 & 0.68 & 0.87 & 0.38 & 0.09 & 4.10 & 430.49 & 0.04 \\
\hline P2-175 & $\mathrm{BC}$ & $44-75$ & 328.63 & 68.07 & 25.00 & 31.16 & 7.98 & 9.85 & 25.67 & 0.36 & 0.49 & 0.47 & 0.35 & 0.07 & 2.95 & 368.66 & 0.08 \\
\hline P3-270 & $\mathrm{E}$ & $0-7$ & 335.69 & 62.66 & 18.99 & 23.85 & 7.89 & 6.99 & 26.45 & 0.35 & 0.37 & 0.19 & 0.35 & 0.08 & 2.87 & 311.77 & 0.13 \\
\hline P3-270 & $\mathrm{Bh}$ & $7-23$ & 324.81 & 63.76 & 20.67 & 22.96 & 8.30 & 7.59 & 26.14 & 0.39 & 0.37 & 0.40 & 0.33 & 0.06 & 2.33 & 311.96 & 0.13 \\
\hline P3-270 & Bw & $23-57$ & 341.35 & 62.58 & 18.43 & 22.14 & 8.28 & 6.82 & 25.69 & 0.36 & 0.34 & 0.34 & 0.32 & 0.08 & 2.20 & 299.55 & 0.12 \\
\hline P3-270 & $\mathrm{BC}$ & $>57$ & 323.13 & 69.07 & 25.87 & 29.10 & 7.68 & 10.03 & 26.11 & 0.35 & 0.45 & 0.39 & 0.34 & 0.07 & 3.02 & 361.04 & 0.08 \\
\hline P4-330 & $\mathrm{E}$ & $0-10$ & 362.91 & 54.13 & 10.81 & 17.29 & 8.05 & 3.48 & 23.24 & 0.32 & 0.27 & 0.06 & 0.27 & 0.20 & 3.39 & 236.55 & 0.10 \\
\hline P4-330 & $\mathrm{Bh}$ & $10-17$ & 317.90 & 65.90 & 25.29 & 24.23 & 7.88 & 9.44 & 23.95 & 0.36 & 0.44 & 0.35 & 0.30 & 0.09 & 3.50 & 322.84 & 0.13 \\
\hline P4-330 & Bhs & $17-17.5$ & 303.58 & 66.76 & 37.76 & 25.69 & 7.27 & 10.12 & 22.91 & 0.30 & 0.46 & 0.34 & 0.30 & 0.08 & 3.67 & 329.71 & 0.57 \\
\hline P4-330 & Bs & $17.5-23$ & 314.20 & 71.50 & 31.18 & 30.53 & 7.97 & 11.84 & 24.85 & 0.34 & 0.53 & 0.37 & 0.31 & 0.08 & 3.59 & 378.19 & 0.12 \\
\hline P4-330 & Bw & $23-63$ & 327.76 & 68.38 & 25.27 & 28.12 & 7.92 & 9.80 & 24.89 & 0.34 & 0.49 & 0.32 & 0.33 & 0.10 & 3.04 & 349.44 & 0.10 \\
\hline P4-330 & $\mathrm{BC} 1$ & $63-113$ & 330.87 & 66.73 & 24.87 & 28.71 & 8.11 & 9.93 & 24.51 & 0.34 & 0.48 & 0.43 & 0.32 & 0.07 & 3.01 & 352.30 & 0.05 \\
\hline P4-330 & $\mathrm{BC} 2$ & 113-193 & 336.78 & 65.32 & 22.31 & 26.90 & 8.37 & 8.84 & 25.08 & 0.38 & 0.47 & 0.37 & 0.34 & 0.07 & 2.59 & 337.48 & 0.05 \\
\hline P4-330 & $\mathrm{BC} 3$ & $>193$ & 320.47 & 70.02 & 28.95 & 33.61 & 7.96 & 11.44 & 25.21 & 0.34 & 0.59 & 0.47 & 0.34 & 0.07 & 3.47 & 391.87 & 0.04 \\
\hline P5-530 & E & $0-8$ & 365.59 & 41.04 & 10.66 & 11.85 & 5.97 & 2.28 & 17.63 & 0.26 & 0.27 & 0.11 & 0.21 & 0.23 & 3.11 & 169.85 & 0.14 \\
\hline P5-530 & $\mathrm{Bh}$ & $8-9.5$ & 326.16 & 53.98 & 19.06 & 18.48 & 7.16 & 4.68 & 21.20 & 0.31 & 0.35 & 0.19 & 0.28 & 0.08 & 4.11 & 241.26 & 0.35 \\
\hline P5-530 & Bhs & $9.5-10$ & 315.66 & 58.03 & 37.94 & 19.49 & 7.48 & 6.44 & 21.97 & 0.30 & 0.30 & 0.16 & 0.27 & 0.10 & 4.04 & 264.89 & 0.60 \\
\hline P5-530 & Bs & $10-15$ & 321.61 & 66.62 & 29.29 & 21.90 & 7.55 & 8.65 & 22.50 & 0.33 & 0.42 & 0.18 & 0.29 & 0.07 & 3.00 & 297.65 & 0.33 \\
\hline P5-530 & Bw & $15-40$ & 327.80 & 68.02 & 26.79 & 27.30 & 8.05 & 10.44 & 25.15 & 0.35 & 0.51 & 0.25 & 0.32 & 0.07 & 3.21 & 352.22 & 0.07 \\
\hline P5-530 & $\mathrm{BC}$ & $40-60$ & 329.07 & 66.98 & 26.28 & 28.45 & 7.99 & 10.44 & 25.02 & 0.34 & 0.51 & 0.26 & 0.32 & 0.07 & 3.09 & 357.10 & 0.05 \\
\hline
\end{tabular}

complexes ii) $\mathrm{Al}$ and Fe in non-crystalline (hydr)oxides, and iii) Fe (and to a smaller extent the $\mathrm{Al}$ ) in crystalline hydrous oxides.

The soil mineralogy of the fine earth fraction $(<2 \mathrm{~mm}$ fraction, crushed to a fine powder with an agate mortar and pestle) has been determined using X-Ray diffraction (XRD). All diffractograms were studied using the X-Ray peak matching software EVA (Bruker) and its database of minerals patterns. The proportions of different crystalline minerals were calculated using SIROQUANT@ 4.0, one of the most recent software using Rietveld refinement (Rietveld, 1969) for quantitative analysis of XRD patterns. SIROQUANT uses full profile fitting routines to generate a synthetic pattern that can be systematically refined via a least-squares minimization of the difference with the diffraction pattern obtained experimentally. The output data also show the error associated with each individual component, the ESD value ("estimated standard deviations" of the weight percentages). These errors are the square roots of the diagonal elements of the least-squares variance covariance matrix. An estimate of the overall goodness of fit for each analysis is also provided in the output, expressed as a global chisquared value. Errors given by Siroquant for each individual mineral determination has to be multiplied by the square root of the global chi^ 2 value for the analysis in question to give the total error per mineral.

\subsection{Rare earth elements analysis and data treatment}

Sample preparations for the rare earth elements (REE) analyses were carried out in clean environment (CEREGE, Aix en Provence). Approximately $250 \mathrm{mg}$ of sample powder ( $<2 \mathrm{~mm}$ fraction, crushed to a fine powder with an agate mortar and pestle) was first treated with $30 \% \mathrm{H}_{2} \mathrm{O}_{2}$ in order to eliminate $\mathrm{OM}$ and then dissolved using a mixture of concentrated $\mathrm{HF}-\mathrm{HNO}_{3}$, followed by concentrated $\mathrm{HCl}$ acids, at $\sim 130{ }^{\circ} \mathrm{C}$. The dissolution was made under laminar flow box in order to minimize sample contamination. The dissolved samples were measured for REE by ICP-MS (NexION 300×, PerkinElmer). To ascertain the accuracy of the REE analysis, two international standards (GSS-2 and GSS-3) were analyzed, using the same technique and during the same analytical session than the "unknown" samples. Those standards were selected because they were estimated to have a REE concentrations close to the ones of the samples, based on the REE concentrations in other podzols in the literature. Furthermore, the repeatability of the analytical technique was verified by analyzing one sample ( $\mathrm{C}$ horizon) in triplicate.
The accuracy of the ICP-MS was estimated by measuring four times the concentrations of each international standards, as an unknown sample. One blank of the sample processing procedure was also included in the analytical session. During the course of the ICP-MS analysis, one blank and one international standard was measured every four samples. The reference and measured values of the international standards, as well as the measured values for the triplicates of the $C$ horizon sample are presented in table $\mathrm{S} 1$. All reagents were ultrapure distilled acids and overall procedural blanks contained negligible quantities of REE compared to the sample REE content. REE concentrations measured in the reference samples were within $90 \%$ of the reference concentrations for these elements and the errors on the measure were $<5 \%$ for most of the REE.

Measured REE concentrations were normalized to both an external (the Upper Continental Crust-UCC (Rudnick and Gao, 2003; Laveuf and Cornu, 2009)) and an internal reference (the parent material from which the soil profile develops after Braun et al., 1998; Aubert et al., 2001; Dequincey et al., 2006), and presented as distribution patterns with the individual REE listed in the order of their atomic number in the $\mathrm{x}$-axis.

Depletion or enrichment of a group or of an individual REE relative to the others was quantified through the calculation of fractionation ratios and anomalies. The fractionation between light REE (LREE, i.e., from La to Nd), medium REE (MREE, i.e. from Sm to Ho) and heavy REEs (HREEs, i.e., from Er to Lu) was quantified by the ratios $\mathrm{La} / \mathrm{Gd}, \mathrm{Gd} / \mathrm{Lu}$ and $\mathrm{La} / \mathrm{Lu}$, calculated after normalization of the concentrations to the parent material. The magnitude of Eu and Ce anomalies (Eu/Eu* and $\left.\mathrm{Ce} / \mathrm{Ce}^{*}\right)$, the only two REE encountered in two oxidation states under earth surface conditions, and that can consequently display a specific behavior, was calculated by the following ratios:

$$
\begin{aligned}
& \mathrm{Ce}-\text { anomaly }=\left[\frac{\mathrm{Ce}}{\mathrm{Ce}{ }^{*}}\right]=\frac{\left(\mathrm{Ce}_{\text {soil }} / \mathrm{Ce}_{\text {ref }}\right)}{\left[\left(\mathrm{La}_{\text {soil }} / \mathrm{La}_{\mathrm{ref}}\right)^{1 / 2}\left(\mathrm{Pr}_{\text {soil }} / \mathrm{Pr}_{\mathrm{ref}}\right)^{1 / 2}\right]} \\
& \mathrm{Eu} \text {-anomaly }=\left[\frac{\mathrm{Eu}}{\mathrm{Eu}^{*}}\right]=\frac{\left(\mathrm{Eu}_{\text {soil }} / \mathrm{Eu}_{\mathrm{ref}}\right)}{\left[\left(\mathrm{Sm}_{\text {soil }} / \mathrm{Sm}_{\mathrm{ref}}\right)^{1 / 2}\left(\mathrm{Gd}_{\text {soil }} / \mathrm{Gd}_{\mathrm{ref}}\right)^{1 / 2}\right]}
\end{aligned}
$$

where the subscript "ref" correspond to the REE concentration in the reference material (UCC or soil parent material) and the subscript 
"soil" correspond to the REE concentration in the soil sample (Mourier et al., 2008; Ndjigui et al., 2008; Vázquez-Ortega et al., 2015).

\section{Results and discussion}

\subsection{REE pattern normalized to the UCC as tracers of soil parent material}

Fig. 2 shows the REE signature of the beach sand (C) and of the deepest BC horizons of the P1-120, P2-175, P3-270, P4-330 and P5530 years profiles normalized to the UCC, while REE concentrations are reported in Table 3. All the considered samples present the same REE pattern depleted in LREE with a strong positive Eu anomaly (Fig. 2 ), confirming that the sediment material at the origin of theses horizons comes from the same source. The strong positive Eu anomaly may be related to the large content in plagioclase of the sediment (Fig. 3 ), since feldspars are known to be enriched in Eu (Vázquez-Ortega et al., 2015).

The $C$ horizon exhibits the highest total content in REE (107.15 $\mu \mathrm{g} \mathrm{REE} \mathrm{g}^{-1}$ soil). This content decreases in the P1-120 BC horizons ( $82.52 \mu \mathrm{g} \mathrm{REE} \mathrm{g}^{-1}$ soil) and in the deep BC horizons of the P2-175, P3-270, P4-330 and P5-530. These four last horizons show similar total REE concentrations $\left(48.89,54.03,57.37\right.$ and $51.87 \mu \mathrm{gEE} \mathrm{g}^{-1}$ soil, respectively). There is no significant evolution of the Eu anomalies, varying from 1.45 to 1.63 when normalized to the UCC.

We observe a decrease in REE concentrations from the beach sand to the $\mathrm{BC}$ horizon of the P1 and a further decrease in the P2-BC horizons of the other soil profiles. Such decrease may be due to mineral weathering. No further REE decrease is recorded in the BC horizons deeper than $50 \mathrm{~cm}$ for older soil profiles (from P2 to P5). In addition, concentrations of $\mathrm{Zr}$ and Ti, two poorly mobile elements that are expected to accumulate with an increasing weathering stage, decrease from the sand beach to P1 and P2 BC horizons $\left(0.23,0.13\right.$ and $0.07 \mathrm{~g} \mathrm{~kg}^{-1}$, respectively, for $\mathrm{Zr}$, and $7.14,5.89$ and $2.95 \mathrm{~g} \mathrm{~kg}^{-1}$, respectively, for Ti), and then remain constant from P2 BC to P5 BC (Table 2). Furthermore, the surface P2 Bw horizon displays higher total concentrations in major elements, $\mathrm{Zr}$, Ti and REE than the deeper P2 BC horizon (Tables 2, 3 and 4). All these observations do not support the hypothesis of an early weathering as explanation for the observed decrease of REE signature in the deep horizons from sand beach to $\mathrm{BC}$ horizon of the P2. It suggests that the decrease in REE from the sand beach to the BC of the P2 is most probably due to a change in the sedimentation dynamic leading to a variable content of sand, silt and clay in the $\mathrm{C}$ beach and $\mathrm{BC}$ horizons. This is consistent with the significant increase in quartz content between $C$ and P1 BC (Fig. 3). Quartz is known to be REE-free and thus acts as a diluting agent of these elements (Compton et al., 2003).

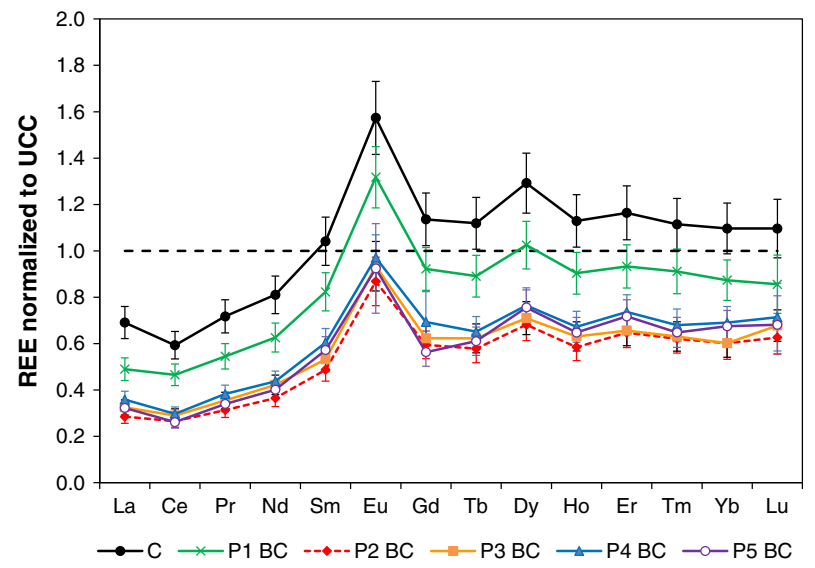

Fig. 2. REE patterns of the $C$ beach parental material and $\mathrm{P} 1-120, \mathrm{P} 2-175, \mathrm{P} 3-270, \mathrm{P} 4-330$ and P5-530 BC, normalized to the UCC. Error bars correspond to the result of error propagation calculations, based on the RSD given by the machine for each measure.
The three podzols, P3-270, P4-330 and P5-530, have similar REE patterns and $\mathrm{Zr}$ and Ti concentrations in their $\mathrm{BC}$ horizons. They may thus be considered as developed from the same parental $\mathrm{BC}$ material. This is confirmed by the similar mineralogical composition of the three $\mathrm{BC}$ horizons (Fig. 3).

In order to identify the impact of podzolization on REE signature, we normalized the REE concentrations of the pedological features to the REE concentrations of the parent material (Braun et al., 1998; Aubert et al., 2001; Dequincey et al., 2006; Laveuf et al., 2008). Therefore, in the following, the mean composition of the $270-330-530$ years BC horizons (mean $\mathrm{BC}, \mathrm{MBC}$ ) will be used as reference value for the parental material of the three podzols, and the REE composition of the three podzolic profiles horizons will be normalized to this value.

\subsection{REE evolution with depth in podzolic soil chronosequence as a tracer of pedogenesis}

Within the podzolic profiles P3-270, P4-330 and P5-530 years, the REE contents of the upper E-horizons are lower than the ones of the BC horizons (a loss of total REE content of 24, 34 and 37\%, respectively, in the $\mathrm{E}$ horizon compared to the deep BC horizon, Fig. 4a, e, i, Fig. 5, and Table 4). The E horizon is the most depleted in the P5 profile. In P3270 years, the REE content already decreases in the Bw horizons compared to the $\mathrm{BC}$ and then remain stable up to the upper $\mathrm{E}$ horizon (Table 3), while in P4, REE concentrations start to decrease from the Bh horizon and from the Bhs in P5. Significant positive correlation was observed between the evolution with depth of REE patterns and of TRB $(r=0.896)$ while a negative correlation was observed with the $\mathrm{Si} / \mathrm{Al}$ ratio $(\mathrm{r}=-0.866)$ (Table 2 , Fig. $4 \mathrm{~b}, \mathrm{f}, \mathrm{j}$ ). The TRB is classically used as a weathering index in soils (Herbillon, 1986) and Si/Al ratio can be considered as a proxy for quartz accumulation at the surface since quartz is a non weatherable mineral in soils. Therefore REE losses are linked to an increase of the weathering stage. Principal mineralogical evolutions with increasing age in the surface horizon (from the P3 E to the P4 E) of the Vancouver chronosequence is a decrease of the modal abundance of primary minerals, except for quartz (Fig.3). Feldspars and quartz are known to contain negligible amounts of REE with the exception of Eu in feldspars (Towell et al., 1969; Condie et al., 1995; Compton et al., 2003). Preferential dissolution of feldspars relative to other REEbearing primary minerals should, therefore, result in negative solid Eu-anomalies. However, no significant evolution of the Eu anomaly was observed in E horizons. The observed signature can originate from the dissolution of other mineral phases present in this horizon (illite, hornblende, augite, chlorite), less abundant in the chronosequence. For example, amphiboles can contain high concentrations in REEs and negative anomalies in Eu (Skublov and Drugova, 2003). The weathering of two minerals with opposite Eu anomalies may explain the absence of change in this anomaly through time. Furthermore, accessory minerals (i.e. heavy minerals and phosphates) are known to present high REE concentrations (Bea, 1996), and to control the presence and dynamics of REE in weathering profiles (Braun et al., 1998).

Heavy minerals known to host REEs are $\mathrm{Zr}$ - and Ti-bearing phases, such as titanite (sphene), anatase, ilmenite and zircon (Braun et al., 1990; Braun et al., 1998; Aubert et al., 2001; Takahashi et al., 2003). Since most of the heavy minerals are rather stable through weathering (Nickel, 1973), the REEs included in these minerals are expected to accumulate in the weathered horizons. Consequently, those phases cannot explain the loss of REE with weathering observed in the E horizon.

Phosphate-bearing minerals (apatite and monazite, xenotime, rhabdophane, etc.) typically contain thousands of $\mathrm{mg} \mathrm{kg}-1$ of REEs (Henderson, 1984; Hughes et al., 1991; Frietsch and Perdahl, 1995; Taunton et al., 2000; Jordens et al., 2013). Consequently, they can largely influence REE content even if small quantity of primary phosphates is present and weathered (Braun et al., 1993; Braun et al., 1998; Aubert et al., 2001; Galan et al., 2007; Stille et al., 2009; Berger et al., 2014; Hissler et al., 2015). Some of these phosphate phases, like apatite, tend 
Table 3

REE contents in the studied podzol samples and in the Upper Continental Crust (UCC).

\begin{tabular}{|c|c|c|c|c|c|c|c|c|c|c|c|c|c|c|c|c|}
\hline \multirow[t]{2}{*}{ Profile } & \multirow[t]{2}{*}{ Horizon } & \multirow{2}{*}{$\frac{\text { Depth }}{\mathrm{cm}}$} & \multicolumn{4}{|c|}{ LREE $\left(\mu g^{-1}\right)$} & \multicolumn{6}{|c|}{$\operatorname{MREE}\left(\mu \mathrm{g} \mathrm{g}^{-1}\right)$} & \multicolumn{4}{|c|}{ HREE $\left(\mu g g^{-1}\right)$} \\
\hline & & & $\mathrm{La}$ & $\mathrm{Ce}$ & $\operatorname{Pr}$ & $\mathrm{Nd}$ & $\mathrm{Sm}$ & $\mathrm{Eu}$ & $\mathrm{Gd}$ & $\mathrm{Tb}$ & Dy & Ho & $\mathrm{Er}$ & $\mathrm{Tm}$ & $\mathrm{Yb}$ & $\mathrm{Lu}$ \\
\hline P.M. & C & & 20.72 & 37.94 & 5.09 & 21.07 & 4.69 & 1.38 & 4.32 & 0.72 & 4.52 & 0.90 & 2.68 & 0.37 & 2.41 & 0.35 \\
\hline P1 & $\mathrm{BC}$ & $0-60$ & 14.69 & 29.80 & 3.87 & 16.28 & 3.70 & 1.16 & 3.50 & 0.57 & 3.59 & 0.72 & 2.15 & 0.30 & 1.92 & 0.27 \\
\hline P2 & Bw & $3-44$ & 10.45 & 21.10 & 2.79 & 11.93 & 2.90 & 0.97 & 2.89 & 0.48 & 3.01 & 0.60 & 1.83 & 0.25 & 1.75 & 0.23 \\
\hline P2 & $\mathrm{BC}$ & $44-75$ & 8.54 & 16.99 & 2.22 & 9.49 & 2.19 & 0.76 & 2.26 & 0.37 & 2.38 & 0.47 & 1.49 & 0.20 & 1.32 & 0.20 \\
\hline P3 & $\mathrm{E}$ & $0-7$ & 7.67 & 14.25 & 1.92 & 7.84 & 1.77 & 0.64 & 1.71 & 0.26 & 1.83 & 0.37 & 1.16 & 0.17 & 1.09 & 0.16 \\
\hline P3 & $\mathrm{Bh}$ & $7-23$ & 7.18 & 13.60 & 1.84 & 7.47 & 1.79 & 0.65 & 1.69 & 0.30 & 1.85 & 0.38 & 1.08 & 0.15 & 1.01 & 0.16 \\
\hline P3 & Bw & $23-57$ & 6.88 & 13.23 & 1.77 & 7.08 & 1.63 & 0.61 & 1.63 & 0.27 & 1.68 & 0.35 & 1.06 & 0.16 & 1.07 & 0.16 \\
\hline P3 & $\mathrm{BC}$ & $>57$ & 9.76 & 18.55 & 2.52 & 10.97 & 2.40 & 0.82 & 2.37 & 0.40 & 2.48 & 0.50 & 1.51 & 0.21 & 1.32 & 0.22 \\
\hline P4 & $\mathrm{E}$ & $0-10$ & 7.34 & 13.33 & 1.80 & 7.45 & 1.60 & 0.52 & 1.35 & 0.23 & 1.51 & 0.30 & 0.92 & 0.14 & 0.96 & 0.13 \\
\hline P4 & $\mathrm{Bh}$ & $10-17$ & 10.13 & 17.84 & 2.45 & 10.07 & 2.30 & 0.77 & 2.10 & 0.37 & 2.42 & 0.47 & 1.46 & 0.20 & 1.28 & 0.19 \\
\hline P4 & Bhs & $17-17.5$ & 11.37 & 20.30 & 2.90 & 11.84 & 2.72 & 0.84 & 2.42 & 0.44 & 2.69 & 0.55 & 1.61 & 0.22 & 1.44 & 0.22 \\
\hline P4 & Bs & $17.5-23$ & 10.27 & 19.32 & 2.74 & 11.83 & 2.77 & 0.91 & 2.62 & 0.47 & 3.09 & 0.61 & 1.82 & 0.25 & 1.67 & 0.24 \\
\hline P4 & Bw & $23-63$ & 9.78 & 19.71 & 2.67 & 11.48 & 2.70 & 0.89 & 2.64 & 0.45 & 2.81 & 0.56 & 1.67 & 0.23 & 1.53 & 0.24 \\
\hline P4 & BC1 & 63-113 & 10.76 & 19.02 & 2.72 & 11.37 & 2.72 & 0.85 & 2.63 & 0.42 & 2.68 & 0.54 & 1.69 & 0.22 & 1.52 & 0.23 \\
\hline P5 & E & $0-8$ & 7.33 & 12.18 & 1.54 & 6.10 & 1.22 & 0.38 & 0.96 & 0.18 & 1.09 & 0.23 & 0.69 & 0.11 & 0.73 & 0.13 \\
\hline P5 & $\mathrm{Bh}$ & $8-9.5$ & 8.28 & 14.42 & 1.99 & 7.93 & 1.71 & 0.53 & 1.40 & 0.24 & 1.60 & 0.34 & 1.02 & 0.14 & 1.06 & 0.16 \\
\hline P5 & Bhs & $9.5-10$ & 8.67 & 14.68 & 1.95 & 8.29 & 1.63 & 0.58 & 1.49 & 0.27 & 1.68 & 0.35 & 1.09 & 0.16 & 1.09 & 0.16 \\
\hline P5 & Bs & $10-15$ & 8.65 & 15.66 & 2.20 & 9.64 & 2.25 & 0.74 & 2.06 & 0.37 & 2.37 & 0.47 & 1.39 & 0.21 & 1.32 & 0.20 \\
\hline P5 & Bw & $15-40$ & 10.33 & 17.41 & 2.43 & 10.26 & 2.51 & 0.74 & 2.17 & 0.40 & 2.57 & 0.51 & 1.52 & 0.22 & 1.42 & 0.21 \\
\hline P5 & $\mathrm{BC}$ & $40-60$ & 9.67 & 16.72 & 2.41 & 10.42 & 2.57 & 0.81 & 2.14 & 0.39 & 2.64 & 0.52 & 1.65 & 0.21 & 1.48 & 0.22 \\
\hline $\mathrm{UCC}^{\mathrm{a}}$ & & & 30.00 & 64.00 & 7.10 & 26.00 & 4.50 & 0.88 & 3.80 & 0.64 & 3.50 & 0.80 & 2.30 & 0.33 & 2.20 & 0.32 \\
\hline
\end{tabular}

a Values for the UCC comes from Laveuf and Cornu (2009).

to disappear in highly weathered material, with significant organic material (Taunton et al., 2000; Berger et al., 2014). In the Vancouver chronosequence podzols, we observe a correlative behavior between the total REE content and the total P content $(r=0.624)$, suggesting that P-phases might play a significant role controlling the REE budget in the weathering profile. The total P content in the E horizon of the P3, P4 and P5 profiles is respectively, 51, 86 and 56\% lower than the content in the BC horizon (Table 2). As those phases, if present, are in small amount, they could not be quantified using the classical XRD method combined with Rietveld analysis.

Furthermore, the signature in the surface horizons is impacted by a preferential decrease of the MREE content, as observed in the profiles P4 and P5 in Fig. 5. This specific signature could result from "M trend", a preferential complexation of the MREE by DOM, impoverishing the solid residue (Tang and Johannesson, 2010). Indeed, some authors observed a MREE enrichment into soil solutions, and hypothesized that this could be a fingerprint of the solubilization of REE bound to OM (Davranche et al., 2011). We observe diagnostic horizons of podzolization in the three podzolic profiles, with an accumulation of OM mainly in the Bh and Bhs horizons in P3, P4 and P5 (Table 1). In addition, we observe an accumulation of $\mathrm{Al}$ and Fe secondary phases (i.e. organo-metallic complexes and short range-ordered $\mathrm{Fe}$ - and $\mathrm{Al}$-(hydr)oxides, in the Bh, Bhs and Bs horizons of P4 (Fig. $4 \mathrm{~g}$ and $\mathrm{h}$ ) and P5 mature podzols (Fig. $4 \mathrm{k}$ and $\mathrm{l}$ ). The majority of the Fe secondary phases are measured in the P4-330 and P5-530 Bhs horizons, as shown by the increase of the ratio $\mathrm{Fe}_{\mathrm{d}} / \mathrm{Fe}_{\mathrm{t}}$ in these horizons (Table 2). These are also the horizons with the highest $C$ content, Fe oxides being known to provide an important mineral surface for the sorption of OM (Dümig et al., 2012). Surprisingly, no accumulation of REE is observed in the Bh-Bhs-Bs horizons of the podzols, despite these horizons contain a high amount of $\mathrm{OM}$ and Fe and $\mathrm{Al}$ oxyhydroxides (Fig. $4 \mathrm{f}$ and j, Fig. 5), known to scavenge REE (Rankin and Childs, 1976; Palumbo et al., 2001; Davranche et al.,
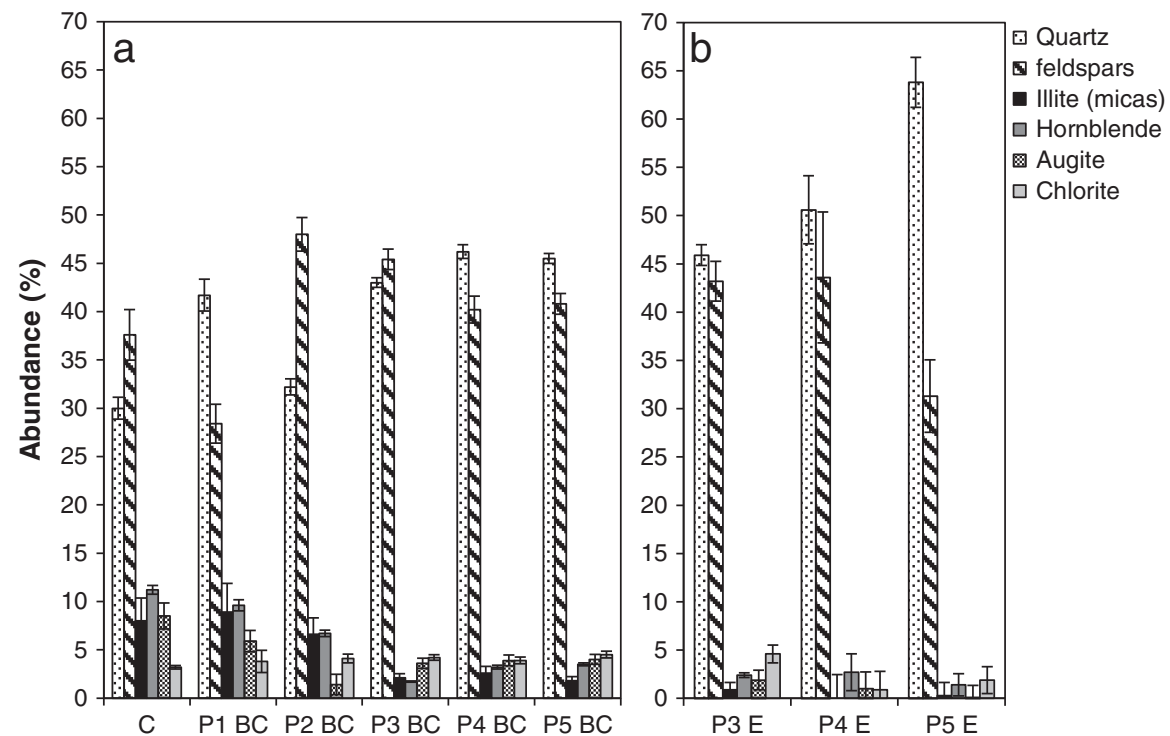

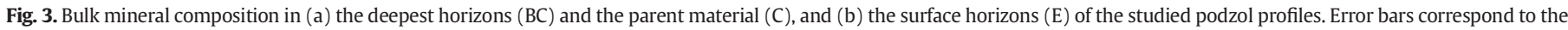

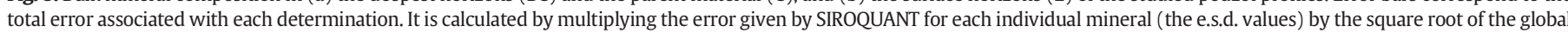
$\chi^{2}$ for the analysis in question. 
Table 4

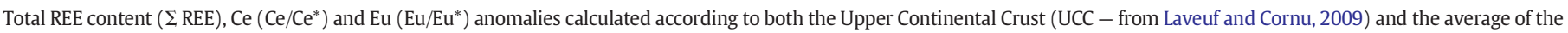
studied BC horizons (MBC), and REE fractionation ratios $(\mathrm{La} / \mathrm{Gd}, \mathrm{Gd} / \mathrm{Lu}, \mathrm{La} / \mathrm{Lu})$ normalized to $\mathrm{MBC}$.

\begin{tabular}{|c|c|c|c|c|c|c|c|c|c|c|}
\hline Profile & Horizon & Depth cm & $\begin{array}{l}\Sigma \mathrm{REE} \\
\mu \mathrm{g} \mathrm{g}^{-1}\end{array}$ & $\mathrm{Ce} / \mathrm{Ce}^{*} \mathrm{UCC}$ & $\mathrm{Eu} / \mathrm{Eu}^{*} \mathrm{UCC}$ & $\mathrm{Ce} / \mathrm{Ce}^{*} \mathrm{MBC}$ & $\mathrm{Eu} / \mathrm{Eu}^{*} \mathrm{MBC}$ & $\mathrm{La} / \mathrm{Gd} \mathrm{MBC}$ & Gd/Lu MBC & $\mathrm{La} / \mathrm{Lu} \mathrm{MBC}$ \\
\hline P.M. & $\mathrm{C}$ & & 107.15 & 0.84 & 1.45 & 1.03 & 0.92 & 1.14 & 1.14 & 1.30 \\
\hline P1 & $\mathrm{BC}$ & $0-60$ & 82.52 & 0.90 & 1.51 & 1.11 & 0.96 & 0.99 & 1.19 & 1.18 \\
\hline P2 & Bw & $3-44$ & 61.16 & 0.89 & 1.57 & 1.09 & 0.99 & 0.86 & 1.18 & 1.01 \\
\hline P2 & $\mathrm{BC}$ & $44-75$ & 48.89 & 0.89 & 1.61 & 1.09 & 1.02 & 0.89 & 1.05 & 0.94 \\
\hline P3 & $\mathrm{E}$ & $0-7$ & 40.85 & 0.85 & 1.74 & 1.04 & 1.10 & 1.06 & 0.99 & 1.05 \\
\hline P3 & $\mathrm{Bh}$ & $7-23$ & 39.15 & 0.85 & 1.75 & 1.05 & 1.11 & 1.01 & 1.00 & 1.01 \\
\hline P3 & Bw & $23-57$ & 37.57 & 0.86 & 1.74 & 1.06 & 1.10 & 1.00 & 0.94 & 0.93 \\
\hline P3 & $\mathrm{BC}$ & $>57$ & 54.03 & 0.85 & 1.62 & 1.05 & 1.03 & 0.97 & 1.01 & 0.99 \\
\hline P4 & $\mathrm{E}$ & $0-10$ & 37.58 & 0.84 & 1.65 & 1.03 & 1.04 & 1.29 & 0.94 & 1.21 \\
\hline P4 & $\mathrm{Bh}$ & $10-17$ & 52.06 & 0.82 & 1.65 & 1.00 & 1.04 & 1.14 & 1.03 & 1.18 \\
\hline P4 & Bhs & $17-17.5$ & 59.57 & 0.81 & 1.53 & 0.99 & 0.97 & 1.11 & 1.03 & 1.14 \\
\hline P4 & Bs & $17.5-23$ & 58.60 & 0.83 & 1.58 & 1.02 & 1.00 & 0.93 & 1.03 & 0.95 \\
\hline P4 & $\mathrm{Bw}$ & $23-63$ & 57.36 & 0.88 & 1.57 & 1.08 & 0.99 & 0.88 & 1.04 & 0.91 \\
\hline P4 & $\mathrm{BC} 1$ & 63-113 & 57.37 & 0.80 & 1.50 & 0.98 & 0.95 & 0.97 & 1.07 & 1.03 \\
\hline P5 & $\mathrm{E}$ & $0-8$ & 32.86 & 0.83 & 1.67 & 1.02 & 1.06 & 1.80 & 0.70 & 1.27 \\
\hline P5 & $\mathrm{Bh}$ & $8-9.5$ & 40.84 & 0.81 & 1.62 & 0.99 & 1.03 & 1.40 & 0.80 & 1.12 \\
\hline P5 & Bhs & $9.5-10$ & 42.09 & 0.81 & 1.76 & 1.00 & 1.11 & 1.37 & 0.84 & 1.16 \\
\hline P5 & $\mathrm{Bs}$ & $10-15$ & 47.54 & 0.82 & 1.62 & 1.00 & 1.03 & 0.99 & 0.97 & 0.96 \\
\hline P5 & Bw & $15-40$ & 52.69 & 0.79 & 1.48 & 0.97 & 0.94 & 1.13 & 0.96 & 1.08 \\
\hline P5 & $\mathrm{BC}$ & $40-60$ & 51.87 & 0.79 & 1.63 & 0.97 & 1.03 & 1.07 & 0.91 & 0.97 \\
\hline
\end{tabular}

2011; Cidu et al., 2013). In addition, no significant correlation was found between total REE, MREE, LREE and HREE, and the Al, Fe and Si extractable secondary phases, nor positive $\mathrm{Ce}$ anomalies, which would be a characteristic feature of REE association with Mn and Fe (Tripathi and Rajamani, 2007; Yusoff et al., 2013). Thus, we suggest that sorption, adsorption, co-precipitation, surface complexes formation, ion exchange and penetration of the lattice of the secondary $\mathrm{Al}$ and Fe phases did not affect significantly the total content of REE in the bulk soil samples of Bh, Bhs and Bs horizons.

We can conclude that the REE patterns in the E-horizons are impacted by weathering but they do not follow the fate of Fe- and Al- oxyhydroxides and OM in the soil profile. However, to further examine the potential of REE to trace illuviation process, we completed our results with additional REE data analyzed in Podzols, available in the literature (see Section 3.3).

\subsection{Pedological processes behind the evolution of the REE signature}

We compared the REE signature evolution of our studied Podzols with those published in the literature (Öhlander et al., 1996; Land et al., 1999; Öhlander et al., 2000; Aubert et al., 2004; Tyler, 2004; Mourier et al., 2008; Vodyanitskii et al., 2011). Our compilation contains

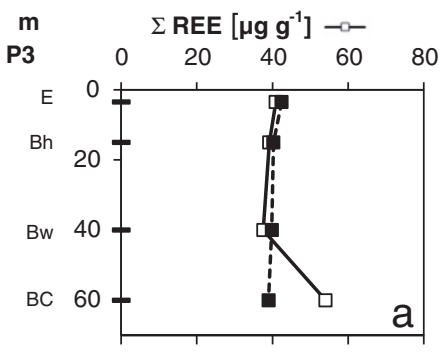

TRB [cmolc kg-1] $\multimap$
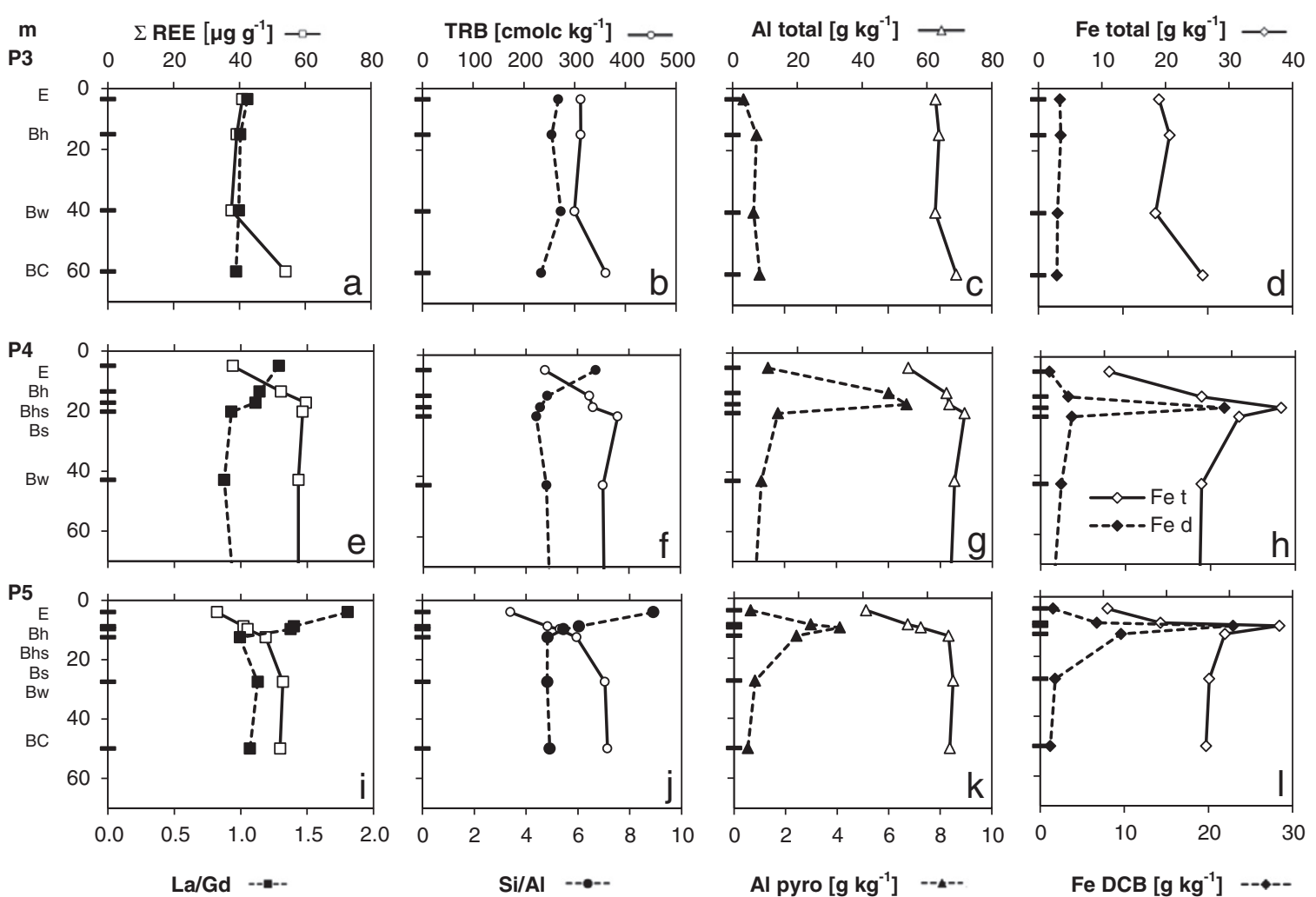

Fig. 4. Total REE, La/Gd, TRB, Si/Al, total and pyrophosphate-extracted Al, total and DCB-extracted Fe - in P3, P4 and P5. 
a

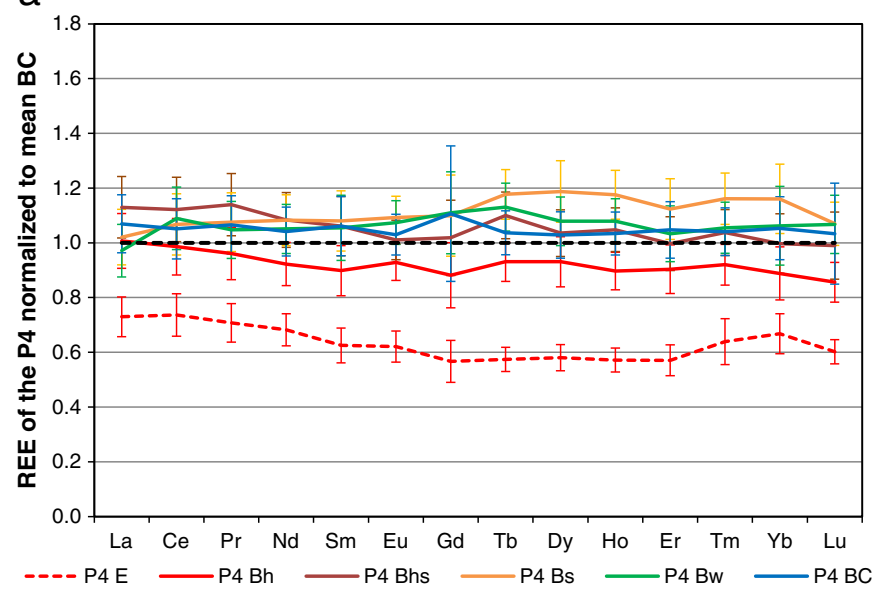

b

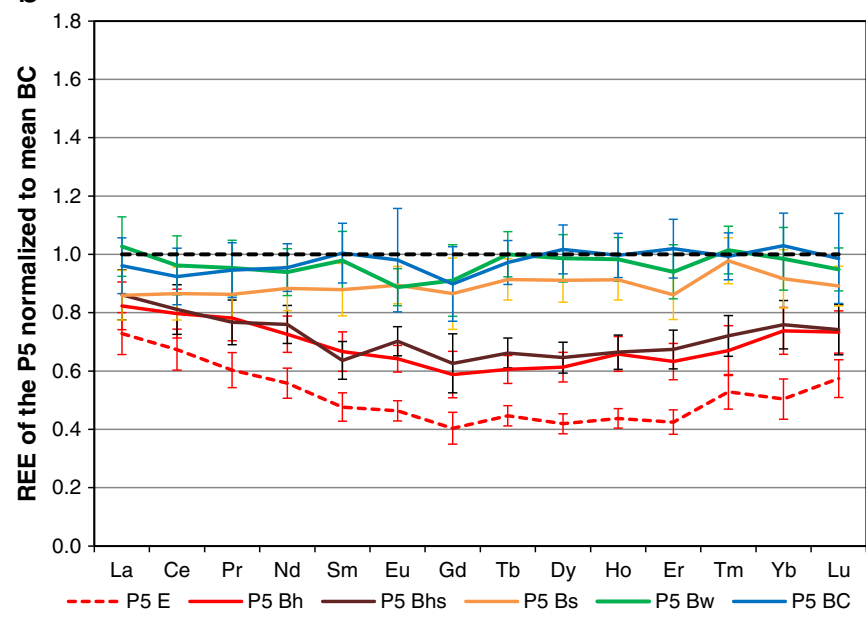

Fig. 5. REE patterns of the P4 horizons (A) and of the P5 horizons (B), normalized to mean $B C$ value of the three podzols. Error bars correspond to the result of error propagation calculations, based on the RSD given by the machine for each measure.

only studies where the REE contents in the E, Bh/Bhs/Bs horizons and the parent material are available (Fig 6). The described podzols developed under a coniferous forest, and in a temperate humid climate. Yet, they are older (between 8700 and 15,000 years old), they have different parent material and they received less precipitations compared to the Podzols from the Vancouver chronosequence (Table 5).

In all Podzols, we observe that the topsoil $\mathrm{E}$ and $\mathrm{B}$ horizons are depleted in REE compared to the parent material (Fig. 6). Losses of REE from the parent material due to weathering has been demonstrated not only for Podzols (Vodyanitskii et al., 2010; Vodyanitskii et al., 2011) but also for other different soil types developed on various parent materials such as granodiorite, Archean granite, serpentinite, shale, etc. (Nesbitt, 1979; Marsh, 1991; Prudencio et al., 1993; Mongelli, 1993; Panahi et al., 2000; Aubert et al., 2001; Ndjigui et al., 2008; Ma et al., 2011).

A second similitude between the podzols is that REE do not accumulate significantly in the $\mathrm{B}(\mathrm{h}, \mathrm{hs}, \mathrm{s})$ horizons compared to the $\mathrm{BC}$ parent material (Figs. 5 and 6). Mourier et al. (2008) also measured the DCB, oxalate and pyrophosphate-extractable $\mathrm{Al}$ and Fe content in the soil samples (Supplementary material, S2), and observed an accumulation of secondary $\mathrm{Al}$ and Fe phases. The accumulation of secondary phases is one order of magnitude lower than the one observed in the P4 and P5 profiles of the Vancouver chronosequence, making even more surprising the absence of REE accumulation in the latter. This confirms our observation that the distribution of Fe, Al-OM complexes and coprecipitates in the soil profile do not significantly contribute to the accumulation of REE in the bulk soil during Podzol development. The main pathway followed by REE during podzolization is a release from the minerals during weathering, and a subsequent leaching with percolating water, resulting to a net loss of REE from the soil profile. This trend is different from the one observed in laterites under (sub)tropical conditions, where REE accumulation in B-horizon is quite common, often associated with $\mathrm{Fe}$ - and Mn-phases in their oxidized form (Braun et al., 1990; Braun et al., 1993; Sanematsu et al., 2011; Berger et al., 2014; Janots et al., 2015). The difference observed between podzolic pedosystems and lateritic soil profiles in humid tropical regions might come from a difference in soil process involved in the REE redistribution and accumulation. Indeed, the podzolization process is mainly controlled by organo-metallic complexation, but the ones involved in the mentioned studies are due to the ferralitization process, where $\mathrm{OM}$ mineralization is fast and where the organo-mineral association phenomenon is less important. The nature of redox process might explain the development or not of an anomaly in Ce, a redox-sensitive element (Nakada et al., 2013). In our chronosequence, we observed no Ce anomaly. Speciation of Ce with organic ligands might be a way to solubilize both $\mathrm{Ce}$ (III) and Ce(IV) without fractionating them (e.g., Janots et al., 2015).

Comparing REE patterns analyzed in the Vancouver Podzols with those published in the literature shows that there is no homogeneity in the fractionation signatures observed in the bulk soil horizons of Podzols (Fig. 6). Land et al. (1999) observe a preferential depletion in LREE, Tyler (2004) a similar depletion of all REE, and Mourier et al. (2008) a preferential MREE depletion, as also observed in our study. This variability can be explained by the variety of factor that can impact the REE signature.

First, various compositions and solubility of minerals present in the soil parent material can partly govern the REE released with weathering. However, the lack of quantification of mineral composition in the published studies, including accessory minerals, prevents further comparison among studies.

Secondly, the type of OM present in solution can play a role in the process of REE complexation, and consequently in the REE mobilized with the organic carrier within the soil profile. The LREE are known to be preferentially bound to carboxylic groups, whereas the HREE are preferentially bound to carboxy-phenolic and phenolic groups (Marsac et al., 2011; Gangloff et al., 2014). Some authors (Yamamoto et al., 2005; Pourret et al., 2007a; Tang and Johannesson, 2010; Davranche et al., 2011; Cidu et al., 2013) make the distinction between a "colloidal pool" (humic acids) in soil waters, enriched in MREE, and a "dissolved pool" with a low REE concentration (complexed with fulvic acids), LREE depleted, but HREE enriched. The type of chemical bonds with organic molecules and the resulting size of the organo-REE complexes can therefore impact the fractionation of REE during weathering and as such the signature of the REE leached from the soil profile.

Finally, the physico-chemical conditions of the solution (e.g. the $\mathrm{pH}$ ) and the other elements present in solution can have an impact on the mobility of REE and interfere with the complexation of REE by OM. Some studies show that for a same OM, the metal loading can affect the preferential affinity for MREE or HREE. Al and Fe may compete with REE in forming organic complexes, and an increase in concentrations of these cations can cause a decrease in the amount of REE bound to dissolved OM (Tang and Johannesson, 2003; Pourret et al., 2007a; Cidu et al., 2013). A MREE enrichment in the liquid phase is shown by patterns at high metal loading, whereas patterns at low metal loading display a regular increase from La to Lu (Marsac et al., 2010), that would imply a preferential loss of HREE from the horizon. The ion activity in soil solution can therefore also substantially govern the preferential leaching of MREE during soil weathering over time.

Further studies, including a characterization of the accessory minerals and the type of DOM present, are needed to determine the relative importance of these factors on the REE fractionation during podzolization. 

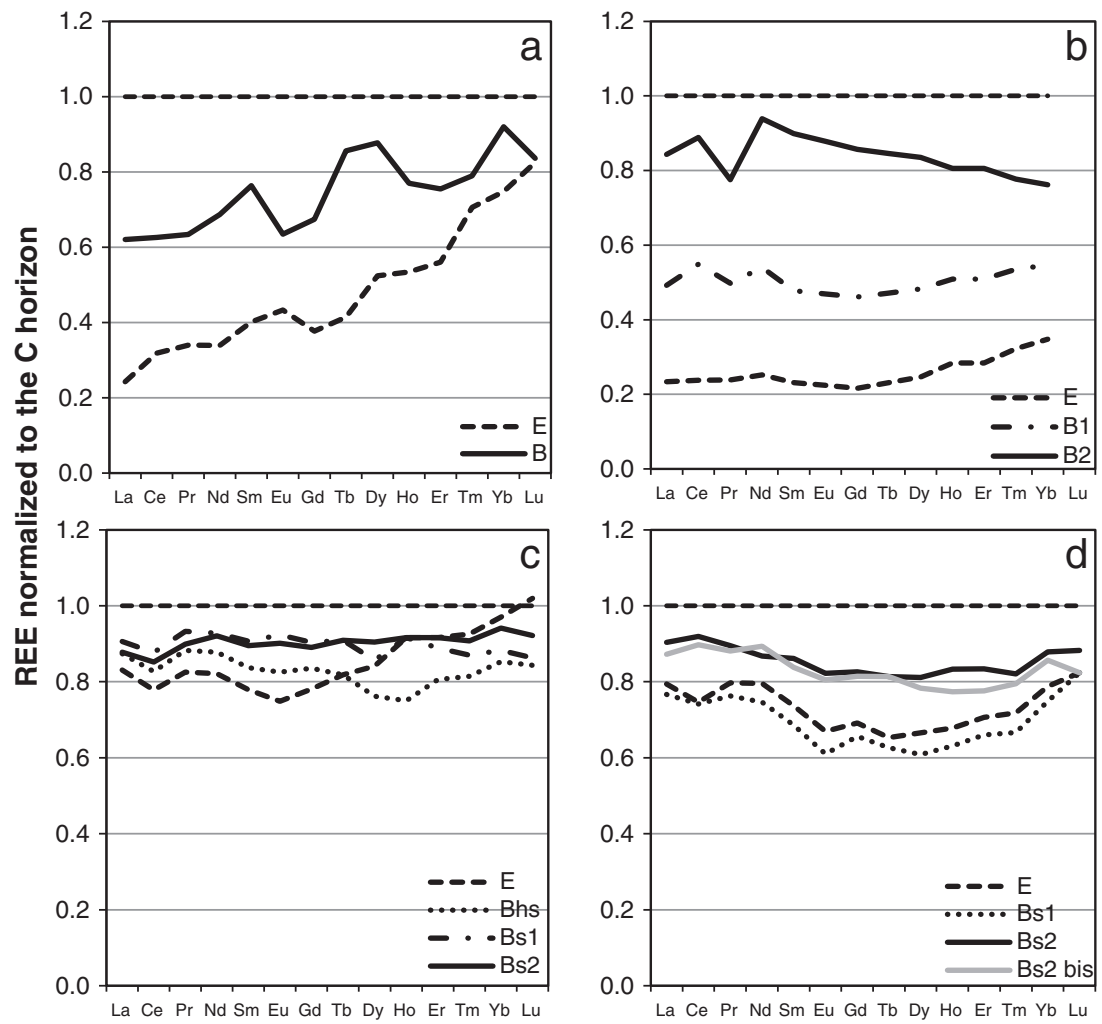

Fig. 6. REE pattern normalized to the C horizon for podzol profiles from the literature: (a) Land et al. (1999); (b) Tyler (2004); (c) and (d) Mourier et al. (2008) - Loup 2 and Orelle 2.

\subsection{Kinetic of weathering in the E horizon of the Podzol chronosequence}

The Fig. 7a presents the evolution of parameters in the E horizon relative to parent material over time in the podzolic soil chronosequence: total REE content, La/Gd ratio (tracing the MREE depletion), TRB (index of soil weathering degree) and $\mathrm{Al} / \mathrm{Si}$ ratio (index of quartz enrichment). Both normalized REE concentrations and TRB decrease in the $\mathrm{E}$ horizon over time. However they do not decrease with the same rate, the TRB decreasing more rapidly than the REEs.

In parallel, both normalized $\mathrm{Si} / \mathrm{Al}$ and $\mathrm{La} / \mathrm{Gd}$ ratios increase over time with the same rate. This confirms the hypothesis that MREE depletion during soil evolution is partly controlled by the weathering of specific silicate minerals (e.g., feldspars, amphiboles, illite) and the enrichment of quartz and some accessory phases.

Previously published studies, focused on REE content in Podzol, present parent material ages ranging between 8700 and 15,000 years (Öhlander et al., 1996; Land et al., 1999; Tyler, 2004; Mourier et al., 2008), or more (Aubert et al., 2001; Aubert et al., 2004), which does not allow determination of the early rates of REE losses, nor the early temporal evolution. Here we show a significant depletion in REE content in the surface E horizon relative to the parent material after $\sim 300$ years. This proves that REE can be released and mobilized in very short periods of time after the beginning of podzolization.

Table 5

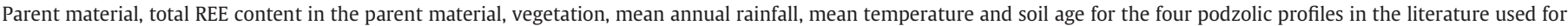
comparison.

\begin{tabular}{|c|c|c|c|c|c|c|}
\hline \multirow[t]{2}{*}{ Reference } & \multirow[t]{2}{*}{ Parent material and/or primary minerals } & \multirow{2}{*}{$\begin{array}{l}\text { Total REE } \\
\text { in the PM } \\
\mu g . g^{-1}\end{array}$} & \multirow[t]{2}{*}{ Vegetation } & \multirow{2}{*}{$\begin{array}{l}\text { Mean annual } \\
\text { rainfall } \\
\mathrm{mm} / \text { year }\end{array}$} & \multirow{2}{*}{$\begin{array}{l}\text { Mean } \mathrm{t}^{\circ} \\
{ }^{\circ} \mathrm{C}\end{array}$} & \multirow{2}{*}{$\begin{array}{l}\text { Soil age } \\
\text { years }\end{array}$} \\
\hline & & & & & & \\
\hline $\begin{array}{l}\text { Mourier et al., } 2008 \\
\text { Loup } 2\end{array}$ & Quartz, muscovite graphite & 255.8 & $\begin{array}{l}\text { Coniferous forest (Pinus cembra and Larix } \\
\text { decidua, Picea abies and Abies alba) Forest } \\
\text { understorey: Vaccinium ulliginosum, } \\
\text { Vaccinium myrtillus and Rhododendron } \\
\text { ferrugineum }\end{array}$ & $947 \pm 184$ & $7.1 \pm 0.6$ & $<15,000$ \\
\hline $\begin{array}{l}\text { Mourier et al., } 2008 \\
\text { Orelle } 2\end{array}$ & $\begin{array}{l}\text { Quartz, muscovite graphite } \\
\text { traces of k-feldspar, albite and zircon } \\
\text { tourmaline apatite }\end{array}$ & 155.7 & $\begin{array}{l}\text { Coniferous forest (Pinus cembra and Larix } \\
\text { decidua, with scattered Picea abies and } \\
\text { Abies alba). Forest understorey: Vaccinium } \\
\text { vitis-idea and Juniperus sibirica }\end{array}$ & $947 \pm 184$ & $7.1 \pm 0.6$ & $<15,000$ \\
\hline Land et al., 1999 & $\begin{array}{l}\text { quartz, plagioclase, K-feldspar, biotite accessory } \\
\text { amounts of amphibole, epidote, zircon, } \\
\text { ilmenite, apatite, garnet, and clay minerals }\end{array}$ & 180.3 & Coniferous forest (spruce and pine) & 500 & -0.2 & 8700 \\
\hline Tyler, 2004 & $\begin{array}{l}\text { moraine, derived from a mixture of quartzite } \\
\text { (Cambrian sandstone) and gneiss (rich in } \\
\text { potassium feldspar) }\end{array}$ & 94.0 & $\begin{array}{l}\text { At least since the Middle Ages: Heather (Calluna } \\
\text { vulgaris). After 1950s: spruce (Picea abies). } \\
\text { Ground vegetation nowadays: Vaccinium } \\
\text { myrtillus, Dicranum scoparium, C. vulgaris, } \\
\text { Deschampsia lexuosa and Pleurozium schreberi }\end{array}$ & 700 & $\begin{array}{l}16 \\
\text { (July)-2 } \\
\text { (January) }\end{array}$ & $13,000-14,000$ \\
\hline
\end{tabular}



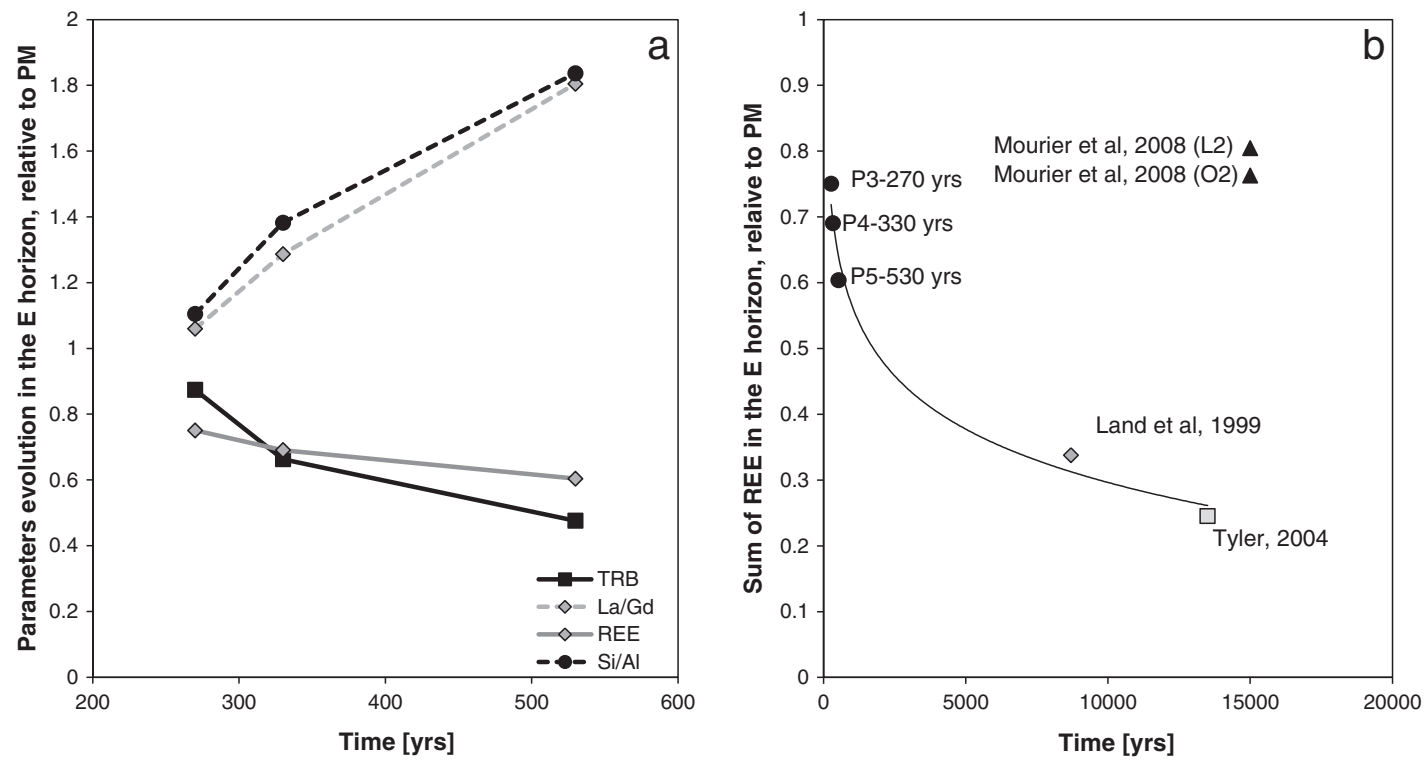

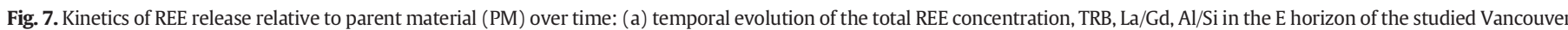

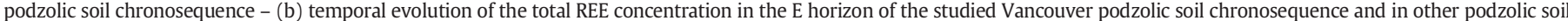
profiles from the literature (Land et al., 1999; Tyler, 2004 and Mourier et al., 2008). A logarithmic fit considering all Podzols, except the two of Mourier et al. (2008) was performed.

When REE loss in the surface E horizon, compared to the PM, of the Podzols in the literature for which the information is available is plotted in function of time (Fig. 7b), a logarithmic decrease is observed for all Podzols, except the two Podzols of Mourier et al. (2008). Such a trend is consistent with the fact that weathering processes are faster at the beginning of pedogenesis, and decrease with time, as the easily weatherable minerals stock decrease. This significant trend $\left(r^{2}=\right.$ 0.9837) of the weathering kinetics is observed for Podzols developed under different climates (rainfall $>4$ times larger in Vancouver Island than in the sites of Land et al., 1999 and Tyler, 2004; Table 5) and from a PM having different total REE content. The mineralogy, even if different between the compared Podzols, has a common point of being rich in quartz and feldspars. The Podzols studied by Mourier et al. (2008) have a very different kinetics, with much lower REE losses compared to the PM. The main difference between the Podzols of Mourier et al. (2008) and the ones of Vancouver Island, Land et al. (1999) and Tyler (2004), is the parent material composed of quartz, muscovite and graphite. Muscovite is known to be more stable than feldspars (Dixon and Weed, 1989), which could explain the weak REE loss after 15,000 years in the surface horizon, even if the PM is relatively rich in REE. The content and composition of accessory minerals, not quantified in this study, may also explain the differences observed.

\section{Conclusion}

Our study shows that a large proportion of REE initially present in the parent material is rapidly lost from the soil profile through mineral weathering and leaching of dissolved elements and/or colloidal particles with percolating water ( 34 and $37 \%$ of loss in the E horizon compared to the BC horizon after 330 and 530 years, respectively). Soilforming factors, such as vegetation and parent material composition can influence soil physico-chemical properties that in turn play a key role in the fractionation of REE during weathering. Environmental conditions are therefore important drivers controlling the rate of REE leached out of soil profile but also the REE signature of soil solution and the preferential leaching of some lanthanides to the hydrosphere.

Furthermore, the accumulation of secondary $\mathrm{OM}, \mathrm{Al}$ and Fe-bearing phases does not impact the REE signature of the bulk soil. Sorption, adsorption, co-precipitation, surface complexes formation, and ion exchange with the secondary $\mathrm{Al}$ and Fe phases are consequently not mechanisms affecting significantly the total content of REE in the Bh, Bhs and Bs horizons.

At last, the demonstration, for the first time, that a large proportion of REE initially present in the parent material can be released and mobilized in very short periods of time during podzolization (330 years) has an important implication for the geochemical behavior of REE at the ecosystem scale and in the hydrological system. Further studies are needed to explain the differential evolutions of signatures in different podzols, and to better understand how the OM and physico-chemical factors impact the release, fractionation and leaching of REE outside the soil profile.

\section{Acknowledgements}

We thank Anne Iserentant and Claudine Givron of the Soil Science and Environment Geochemistry lab (Earth and Life institute, Université catholique de Louvain, Belgium) for the analysis with the ICP-AES and help with labwork. We thank Les Lavkulich for his help with fieldwork. Financial support was provided by the Fond de la Recherche Scientifique (F.R.S.-FNRS, Belgium), through a FRFC project. We also thank Bernard Angeletti from CEREGE (UMR 7330 Aix Marseille Université - CNRS) for his help with the ICP MS analysis.

\section{Appendix A Supplementary data}

Supplementary data associated with this article can be found in the online version, at http://dx.doi.org/10.1016/j.chemgeo.2016.06.008. These data include Google map of the most important areas described in this article.

\section{References}

Aide, M., Smith-Aide, C., 2003. Assessing soil genesis by rare-earth elemental analysis. Soil Sci. Soc. Am. J. 67, 1470-1476.

Aide, M.T., Aide, C., 2012. Rare earth elements: their importance in understanding soil genesis. ISRN Soil Sci. 2012, 1-11.

Aubert, D., Probst, A., Stille, P., 2004. Distribution and origin of major and trace elements (particularly REE, $U$ and Th) into labile and residual phases in an acid soil profile (Vosges Mountains, France). Appl. Geochem. 19, 899-916.

Aubert, D., Stille, P., Probst, A., 2001. REE fractionation during granite weathering and removal by waters and suspended loads: $\mathrm{Sr}$ and $\mathrm{Nd}$ isotopic evidence. Geochim. Cosmochim. Acta 65, 387-406. 
Bascomb, C.L., 1968. Distribution of pyrophosphate-extractable iron and organic carbon in soils of various groups. J. Soil Sci. 19, 251-268.

Bea, F., 1996. Residence of REE, Y, Th and U in granites and crustal protoliths; implications for the chemistry of crustal melts. J. Petrol. 37, 521-552.

Berger, A., Janots, E., Gnos, E., Frei, R., Bernier, F., 2014. Rare earth element mineralogy and geochemistry in a laterite profile from Madagascar. Appl. Geochem. 41, 218-228.

Blakemore, L.C., S., P.L., Daly, B.K., 1987. Methods for Chemical Analysis of Soils (Lower Hutt, N.Z.).

Braun, J.-J., Pagel, M., Muller, J.-P., Bilong, P., Michard, A., Guillet, B., 1990. Cerium anomalies in lateritic profiles. Geochim. Cosmochim. Acta 54, 781-795.

Braun, J.J., Pagel, M., Herbilln, A., ROSIN, C., 1993. Mobilization and redistribution of REEs and thorium in a syenitic lateritic profile: a mass balance study. Geochim. Cosmochim. Acta 57, 4419-4434.

Braun, J.J., Viers, J., Dupré, B., Polve, M., Ndam, J., Muller, J.P., 1998. Solid/liquid REE fractionation in the lateritic system of Goyoum, East Cameroon: the implication for the present dynamics of the soil covers of the humid tropical regions. Geochim. Cosmochim. Acta 62, 273-299.

Cao, X., Chen, Y., Wang, X., Deng, X., 2001. Effects of redox potential and pH value on the release of rare earth elements from soil. Chemosphere 44, 655-661.

Chabaux, F., Dequincey, O., Lévèque, J.-J., Leprun, J.-C., Clauer, N., Riotte, J., Paquet, H., 2003. Tracing and dating recent chemical transfers in weathering profiles by trace-element geochemistry and $238 \mathrm{U} 234 \mathrm{U} 230$ Th disequilibria: the example of the Kaya lateritic toposequence (Burkina-Faso). Compt. Rendus Geosci. 335, 1219-1231.

Chao, T.T., 1976. The significance of secondary iron and manganese oxides in geochemical exploration. Econ. Geol. 71, 1560-1569.

Chao, T.T., Sanzolone, R.F., 1992. Decomposition techniques. J. Geochem. Explor. 44 65-106.

Cidu, R., L., V.A., Biddau, R., Buscaroli, A., Carbone, S., Da Pelo, S., Dinelli, E., Vianello, G., Zannoni, D., 2013. Dynamics of rare earth elements in water-soil systems: the case study of the Pineta San Vitale (Ravenna, Italy). Geoderma 193-194, 52-67.

Compton, J.S., White, R.A., Smith, M., 2003. Rare earth element behavior in soils and salt pan sediments of a semi-arid granitic terrain in the Western Cape, South Africa. Chem. Geol. 201, 239-255.

Condie, K.C., Dengate, J., Cullers, R.L., 1995. Behavior of rare earth elements in a paleoweathering profile on granodiorite in the Front Range, Colorado, USA. Geochim. Cosmochim. Acta 59, 279-294.

Cordes, D.L., 1972. An Ecological Study of the Sitka Spruce Forest on the West Coast of Vancouver Island. University of British Columbia.

Cornelis, J.-T., Weis, D., Lavkulich, L., Vermeire, M.-L., Delvaux, B., Barling, J., 2014. Silicon isotopes record dissolution and re-precipitation of pedogenic clay minerals in a podzolic soil chronosequence. Geoderma 235-236, 19-29.

Cornu, S., Besnault, A., Bermond, A., 2008. Soil podzolization induced by reforestation as shown by sequential and kinetic extractions of Fe and Al. Eur. J. Soil Sci. 59, 222-232.

Davranche, M., Grybos, M., Gruau, G., Pédrot, M., Dia, A., Marsac, R., 2011. Rare earth element patterns: a tool for identifying trace metal sources during wetland soil reduction. Chem. Geol. 284, 127-137.

Dequincey, O., Chabaux, F., Leprun, J.C., Paquet, H., Clauer, N., Larque, P., 2006. Lanthanide and trace element mobilization in a lateritic toposequence: inferences from the Kaya laterite in Burkina Faso. Eur. J. Soil Sci. 57, 816-830.

Dixon, J.B., Weed, S.B., 1989. Minerals in Soil Environments. SSSA Book Ser. 1. SSSA (Madison, WI.2ed).

Dümig, A., Häusler, W., Steffens, M., Kögel-Knabner, I., 2012. Clay fractions from a soil chronosequence after glacier retreat reveal the initial evolution of organo-minera associations. Geochim. Cosmochim. Acta 85, 1-18.

Frietsch, R., Perdahl, J.-A., 1995. Rare earth elements in apatite and magnetite in Kirunatype iron ores and some other iron ore types. Ore Geol. Rev. 9, 489-510.

Galan, E., Fernandez-Caliani, J., Miras, A., Aparicio, P., Marquez, M., 2007. Residence and fractionation of rare earth elements during kaolinization of alkaline peraluminous granites in NW Spain. Clay Miner. 42, 341-352.

Gangloff, S., Stille, P., Pierret, M.-C., Weber, T., Chabaux, F., 2014. Characterization and evolution of dissolved organic matter in acidic forest soil and its impact on the mobility of major and trace elements (case of the Strengbach watershed). Geochim. Cosmochim. Acta 130, 21-41.

Gong, Q., Deng, J., Yang, L., Zhang, J., Wang, Q., Zhang, G., 2011. Behavior of major and trace elements during weathering of sericite-quartz schist. J. Asian Earth Sci. 42, $1-13$.

Goyne, K.W., Brantley, S.L., Chorover, J., 2010. Rare earth element release from phosphate minerals in the presence of organic acids. Chem. Geol. 278, 1-14.

Harlavan, Y., Erel, Y., Blum, J.D., 2009. The coupled release of REE and Pb to the soil labile pool with time by weathering of accessory phases, Wind River Mountains, WY. Geochim. Cosmochim. Acta 73, 320-336.

Henderson, P., 1984. General geochemical properties and abundances of the rare earth elements. Rare Earth Element Geochemistry. Elsevier, Amsterdam.

Henriet, C., De Jaeger, N., Dorel, M., Opfergelt, S., Delvaux, B., 2008. The reserve of weatherable primary silicates impacts the accumulation of biogenic silicon in volcanic ash soils. Biogeochemistry 90, 209-223.

Herbillon, A.J., 1986. Chemical estimation of weatherable minerals present in the diagnostic horizons of low activity clay soils. In: Beinroth, M.N., Camargo, M.N., Eswaran, H. (Eds.), Proceedings of the 8th International Classification Workshop: Classification, Characterization, and Utilization of Ultisols. Part I. EMBRAPA, Rio de Janeiro, pp. 39-48.

Hissler, C., Stille, P., Juilleret, J., Iffly, J.F., Perrone, T., Morvan, G., 2015. Elucidating the formation of terra fuscas using $\mathrm{Sr}-\mathrm{Nd}-\mathrm{Pb}$ isotopes and rare earth elements. Appl. Geochem. 54, 85-99.

Hu, Z., Haneklaus, S., Sparovek, G., Schnug, E., 2006. Rare earth elements in soils. Commun. Soil Sci. Plant Anal. 37, 1381-1420.
Huggett, R., 1998. Soil chronosequences, soil development, and soil evolution: a critical review. Catena 32, 155-172.

Hughes, J.M., Cameron, M., Mariano, A.N., 1991. Rare-earth-element ordering and structural variations in natural rare-earth-bearing apatites. Am. Mineral. 76, 1165-1173.

IUSS Working Group WRB, 2014. World reference base for soil resources 2014: international soil classification system for naming soils and creating legends for soil maps. World Soil Resources Reports 106. FAO, Rome.

Janots, E., Bernier, F., Brunet, F., Muñoz, M., Trcera, N., Berger, A., Lanson, M., 2015. Ce(III) and $\mathrm{Ce}(\mathrm{IV})$ (re)distribution and fractionation in a laterite profile from Madagascar: insights from in situ XANES spectroscopy at the Ce LIII-edge. Geochim. Cosmochim. Acta $153,134-148$.

Johannesson, K.H., Tang, J., Daniels, J.M., Bounds, W.J., Burdige, D.J., 2004. Rare earth element concentrations and speciation in organic-rich blackwaters of the great dismal swamp, Virginia, USA. Chem. Geol. 209, 271-294.

Jordens, A., Cheng, Y.P., Waters, K.E., 2013. A review of the beneficiation of rare earth element bearing minerals. Miner. Eng. 41, 97-114.

Kaiser, K., Kalbitz, K., 2012. Cycling downwards - dissolved organic matter in soils. Soil Biol. Biochem. 52, 29-32.

Koeppenkastrop, D., De Carlo, E.H., 1992. Sorption of rare-earth elements from seawater onto synthetic mineral particles: an experimental approach. Chem. Geol. 95, 251-263.

Land, M., Öhlander, B., Ingri, J., Thunberg J., 1999. Solid speciation and fractionation of rare earth elements in a spodosol profile from northern Sweden as revealed by sequential extraction. Chem. Geol. 160, 121-138.

Laveuf, C., Cornu, S., 2009. A review on the potentiality of rare earth elements to trace pedogenetic processes. Geoderma 154, 1-12.

Laveuf, C., Cornu, S., Juillot, F., 2008. Rare earth elements as tracers of pedogenetic processes. Compt. Rendus Geosci. 340, 523-532.

Li, F.-M., Wang X.-L., Li, Y., Guo, S.-H., Zhong A.-P., 2006. Selective extraction and separation of Fe, Mn oxides and organic materials in river surficial sediments. J. Environ. Sci. $18,1233-1240$.

Lundström, U., Van, N., Bain, D., 2000. The podzolization process. A review. Geoderma.

Ma, L., Jin, L., Brantley, S.L., 2011. How mineralogy and slope aspect affect REE release and fractionation during shale weathering in the Susquehanna/Shale Hills critical zone observatory. Chem. Geol. 290, 31-49.

Marsac, R., Davranche, M., Gruau, G. Bouhnik-Le Coz, M., Dia, A. 2011. An improved description of the interactions between rare earth elements and humic acids by modeling: PHREEQC-model VI coupling. Geochim. Cosmochim. Acta 75, 5625-5637.

Marsac, R., Davranche, M., Gruau, G., Dia, A., 2010. Metal loading effect on rare earth element binding to humic acid: experimental and modelling evidence. Geochim. Cosmochim. Acta 74, 1749-1761.

Marsh, J.S., 1991. REE fractionation and Ce anomalies in weathered Karoo dolerite. Chem. Geol. 90, 189-194.

Mckeague, J., Ross, G., Gamble, D., Mahaney, W., 1978. Properties, criteria of classification and genesis of podzolic soils in Canada. Quaternary Soils 27-60.

Mehra, O.P., Jackson, M.L., 1960. Iron oxide removal from soils and clays by a dithionitecitrate system buffered with sodium bicarbonate. Clay Clay Miner. 7, 317-327.

Mongelli, G., 1993. REE and other trace elements in a granitic weathering profile from "Serre", southern Italy. Chem. Geol. 103, 17-25.

Mourier, B., Poulenard, J., Chauvel, C., Faivre, P., Carcaillet, C., 2008. Distinguishing subalpine soil types using extractible $\mathrm{Al}$ and Fe fractions and REE geochemistry. Geoderma $145,107-120$.

Muller, J.E., Carson, D.J.T., 1969. Geology and mineral deposits of alberni map-area, British Columbia. Geol. Surv. Can.

Nakada, R., Takahashi, Y., Tanimizu, M., 2013. Isotopic and speciation study on cerium during its solid-water distribution with implication for Ce stable isotope as a paleoredox proxy. Geochim. Cosmochim. Acta 103, 49-62.

Ndjigui, P.-D., Bilong, P., Bitom, D., DIA, A., 2008. Mobilization and redistribution of major and trace elements in two weathering profiles developed on serpentinites in the Lomié ultramafic complex, South-East Cameroon. J. Afr. Earth Sci. 50, 305-328.

Nesbitt, H.W., 1979. Mobility and Fractionation of Rare Earth Elements during Weathering of a Granodiorite.

Nickel, E., 1973. Experimental dissolution of light and heavy minerals in comparison with weathering and intrastratal solution. Contrib. Sedimentol. 1, 1-68.

Öhlander, B., Ingri, J., Land, M., Schöberg, H., 2000. Change of Sm-Nd isotope composition during weathering of till. Geochim. Cosmochim. Acta 64, 813-820.

Öhlander, B., Land, M., Ingri, J., Widerlund, A., 1996. Mobility of rare earth elements during weathering of till in northern Sweden. Appl. Geochem. 11, 93-99.

Page, J.R., Miller, R.H., Keeney, D.H., Baker, D.E., Roscoe, J.R., R., J.D. (Eds.), 1982. Methods of soil analysis: part 2, chemical and microbiological properties, second ed. (Madison, WI).

Palumbo, B., Bellanca, A., Neri, R., Roe, M.J., 2001. Trace metal partitioning in Fe-Mn nodules from Sicilian soils, Italy. Chem. Geol. 173, 257-269.

Panahi, A., Young, G.M., Rainbird, R.H., 2000. Behavior of major and trace elements (including REE) during Paleoproterozoic pedogenesis and diagenetic alteration of an $\mathrm{Ar}$ chean granite near Ville Marie, Quebec, Canada. Geochim. Cosmochim. Acta 64, 2199-2220.

Pedrot, M., Dia, A., Davranche, M., Bouhnik-Le Coz, M., Henin, O., Gruau, G., 2008. Insights into colloid-mediated trace element release at the soil/water interface. J. Colloid Interface Sci. 325, 187-197.

Pourret, O., Davranche, M., Gruau, G., Dia, A., 2007a. Organic complexation of rare earth elements in natural waters: evaluating model calculations from ultrafiltration data. Geochim. Cosmochim. Acta 71, 2718-2735.

Pourret, O., Davranche, M., Gruau, G., Dia, A., 2007b. Rare earth elements complexation with humic acid. Chem. Geol. 243, 128-141.

Prudencio, M., Braga, M., Gouveia, M., 1993. REE mobilization, fractionation and precipitation during weathering of basalts. Chem. Geol. 107, 251-254. 
Rankin, P.C., Childs, C.W., 1976. Rare-earth elements in iron-manganese concretions from some New Zealand soils. Chem. Geol. 18, 55-64.

Rietveld, H., 1969. A profile refinement method for nuclear and magnetic structures. J. Appl. Crystallogr. 2, 65-71.

Rudnick, R.L., Gao, S., 2003. 3.01 - composition of the continental crust. In: Turekian, H.D.H.K. (Ed.), Treatise on Geochemistry. Pergamon, Oxford.

Saatz, J., Vetterlein, D., Mattusch, J., Otto, M., Daus, B., 2015. The influence of gadolinium and yttrium on biomass production and nutrient balance of maize plants. Environ. Pollut. 204, 32-38.

Sanematsu, K., Moriyama, T., Sotouky, L., Watanabe, Y., 2011. Mobility of rare earth elements in basalt-derived laterite at the Bolaven Plateau, Southern Laos. Resour. Geol. 61, 140-158.

Sauer, D., Schülli-Maurer, I., Sperstad, R., Sørensen, R., Stahr, K., 2008. Podzol development with time in sandy beach deposits in southern Norway. J. Plant Nutr. Soil Sci. 171, 483-497.

Singleton, G.A., Lavkulich, M., 1987. A soil chronosequence on beach sands, Vancouver Island, British Columbia. Can. J. Soil Sci. 67, 795-810.

Skublov, S., Drugova, G., 2003. Patterns of trace-element distribution in calcic amphiboles as a function of metamorphic grade. Can. Mineral. 41, 383-392.

Sonke, J.E., 2006. Lanthanide-humic substances complexation. II. Calibration of humic ionbinding model V. Environ. Sci. Technol. 40, 7481-7487.

Sonke, J.E., Salters, V.J.M., 2006. Lanthanide-humic substances complexation. I. Experimental evidence for a lanthanide contraction effect. Geochim. Cosmochim. Acta 70, 1495-1506.

Stern, J.C., Sonke, J.E., Salters, V.J., 2007. A capillary electrophoresis-ICP-MS study of rare earth element complexation by humic acids. Chem. Geol. 246, 170-180.

Stille, P., Pierret, M.-C., Steinmann, M., Chabaux, F., Boutin, R., Aubert, D., Pourcelot, L., Morvan, G., 2009. Impact of atmospheric deposition, biogeochemical cycling and water-mineral interaction on REE fractionation in acidic surface soils and soil water (the Strengbach case). Chem. Geol. 264, 173-186.

Takahashi, Y., Sakashima, T., Shimizu, H., 2003. Observation of tetravalent cerium in zircon and its reduction by radiation effect. Geophys. Res. Lett. 30, 37-41.

Tang, J., Johannesson, K.H., 2003. Speciation of rare earth elements in natural terrestrial waters: assessing the role of dissolved organic matter from the modeling approach. Geochim. Cosmochim. Acta 67, 2321-2339.

Tang, J., Johannesson, K.H., 2010. Ligand extraction of rare earth elements from aquifer sediments: implications for rare earth element complexation with organic matter in natural waters. Geochim. Cosmochim. Acta 74, 6690-6705.

Taunton, A.E., Welch, S.A., Banfield, J.F., 2000. Microbial controls on phosphate and lanthanide distributions during granite weathering and soil formation. Chem. Geol. 169, 371-382.
Towell, D.G., Spirn, R.V., Winchester, J.W., 1969. Europium anomalies and the genesis of basalt: a discussion. Chem. Geol. 4, 461-464.

Tripathi, J.K., Rajamani, V., 2007. Geochemistry and origin of ferruginous nodules in weathered granodioritic gneisses, Mysore Plateau, Southern India. Geochim. Cosmochim. Acta 71, 1674-1688.

Tyler, G., 2004. Vertical distribution of major, minor, and rare elements in a Haplic Podzol. Geoderma 119, 277-290.

Van Hees, P.A.W., Lundström, U.S., Giesler, R., 2000. Low molecular weight organic acids and their Al-complexes in soil solution-composition, distribution and seasonal variation in three podzolized soils. Geoderma 94, 173-200.

Vázquez-ORTEGA, A., Perdrial, J., Harpold, A., Zapata-Ríos, X., Rasmussen, C., Mcintosh, J. Schaap, M., Pelletier, J.D., Brooks, P.D., Amistadi, M.K., Chorover, J., 2015. Rare earth elements as reactive tracers of biogeochemical weathering in forested rhyolitic terrain. Chem. Geol. 391, 19-32.

Vodyanitskii, Y.N., Goryachkin, S.V Savichev, A.T, 2011. Distribution of rare-earth (Y, La $\mathrm{Ce}$ ) and other heavy metals in the profiles of the podzolic soil group. Eurasian Soil Science 44, 500-509.

Vodyanitskii, Y.N., Savichev, A.T., Vasil'ev, A.A., Lobanova, E.S., Chashchin, A.N., Prokopovich, E.V., 2010. Contents of heavy alkaline-earth (Sr, Ba) and rare-earth (Y, $\mathrm{La}, \mathrm{Ce})$ metals in technogenically contaminated soils. Eurasian Soil Science 43, 822-832.

Walker, L.R., Wardle, D.A., Bardgett, R.D., Clarkson, B.D., 2010. The use of chronosequences in studies of ecological succession and soil development. J. Ecol. 98, 725-736.

Wang, Q., Huang, B., Guan, Z., Yang, L., Li, B., 2001. Speciation of rare earth elements in soi by sequential extraction then HPLC coupled with visible and ICP-MS detection. Anal. Bioanal. Chem. 370, 1041-1047.

Yamamoto, Y., Takahashi, Y., Shimizu, H., 2005. Systematics of stability constants of fulvate complexes with rare earth ions. Chem. Lett. 34, 880-881.

Yan, X.-P., Kerrich, R., Hendry, MJ. 1999. Sequential leachates of multiple grain size fractions from a clay-rich till, Saskatchewan, Canada: implications for controls on the rare earth element geochemistry of porewaters in an aquitard. Chem. Geol. 158, 53-79.

Yusoff, Z.M., Ngwenya, B.T., Parsons, I., 2013. Mobility and fractionation of REEs during deep weathering of geochemically contrasting granites in a tropical setting, Malaysia. Chem. Geol. 349-350, 71-86.

Zhang, S., Shan, X.-Q., 2001. Speciation of rare earth elements in soil and accumulation by wheat with rare earth fertilizer application. Environ. Pollut. 112, 395-405. 